\title{
Adaptations to Sea Level Rise: A Tale of Two Cities - Venice and Miami
}

\author{
Emanuela Molinaroli ${ }^{\mathrm{A}} \#$, Stefano Guerzoni ${ }^{\mathrm{b}}$, and Daniel Suman ${ }^{\mathrm{c}}$ \\ ${ }^{a}$ Dipartimento di Scienze Ambientali, Informatica e Statistica, Università CaFoscari, Campus \\ Scientifico Mestre-Venice (Italy), e-mail:molinaro@unive.it \\ ${ }^{b}$ International Marine Center, Torregrande, Loc. Sa Mardini - 09170 Oristano (Italy), e-mail: \\ s.guerzoni@fondazioneimc.it \\ ${ }^{c}$ Department of Marine Ecosystems and Society, Rosenstiel School of Marine and Atmospheric \\ Science, University of Miami, Miami, Florida (USA), email: dsuman@rsmas.miami.edu
}

(\#) corresponding author: molinaro@unive.it

Declarations of interest: none'

\begin{abstract}
Both Venice and Miami are highly vulnerable to sea level rise and climate change. Their large populations; valuable infrastructure, real estate and cultural heritage; sea level location; high economic dependency on tourism; as well as their access to advanced scientific data and technological expertise point to their similarities. Yet their responses have been quite different. We examine the two cities' biophysical environments, their socioeconomic bases, the legal and administrative structures, and their vulnerabilities and responses to sea level rise and flooding. Our study uses a qualitative approach to illustrate how governance addressing adaptation has emerged in the two coastal cities. Based on this information we critically compare the different adaptive responses of Venice and Miami and suggest what each city may learn from the other, as well as offer lessons for other vulnerable coastal cities. Decisionmakers must address the complex issue of rising seas by a combination of scientific knowledge and socio-economic expertise.
\end{abstract}

Keywords: sea level rise, flooding, vulnerability, adaptation, coastal cities 


\section{Introduction}

Climate change is expected to have severe impacts on coastal areas in particular due to sea level rise (SLR). This can increase flood risk, coastal erosion and loss of low-lying systems (e.g. deltas, coastal lagoons, barrier islands) due to permanent inundation (Kirwan and Megonigal, 2013; EEA, 2015; Passeri et al., 2015). The most recent mean global SLR projections by the Intergovernmental Panel on Climate Change (IPCC, 2014) range from $0.32-0.63 \mathrm{~m}$ by $2081-2100$ for the RCP4.5 and RCP6.0 emissions scenarios. Other IPCC emission scenarios increase the likely envelope to 0.26-0.82 m (IPCC, 2014). Independent estimates of future sea level suggest that global SLR could approach or possibly exceed $1 \mathrm{~m}$ by 2100 (Pfeffer et al., 2008; Vermeer and Rahmstorf, 2009; Nicholls, 2011; Kopp et al., 2016; Antonioli et al., 2017). Other estimates predict that sea level rises of up to 2 meters due to the contribution of Antarctica's melting (De Conto and Pollard, 2016).

The impact of SLR is not felt equally around the globe; some locations experience greater rise than others because of local terrain, local hydrological factors, and oceanic currents, among other regional factors (Thead, 2016). Several studies examined the vulnerabilities of global coastal cities to climate hazards. Among them, De Sherbinin et al. (2007) described the vulnerabilities of Mumbai, Rio de Janeiro, and Shanghai discussing the implications of the results for city planners and managers and highlighting some of the political obstacles to better disaster preparedness. Varrani and Nones (2017) compared Jakarta and Venice and suggested a mixed approach of adaptable planning instruments that consider future uncertainties. Fu et al. (2016) compared adaptive planning strategies for sea level rise of US coastal cities. The emphasis of climate change policy has largely focussed on mitigation. As necessary as these efforts are, more attention should be given to adaptation to the climatic changes that are already underway and will be exacerbated by future emissions of greenhouse gases (De Sherbinin et al., 2007).

The present work critically compares the regions surrounding Venice, Italy and Miami, Florida, USA, that both experience recent acceleration of the SLR in relation to other zones of the respective countries. Our analysis utilizes both archival and observational methodologies, as the authors are researchers in both cities who are closely involved in SLR adaptation issues. Our work analyzes the physical and socio-economic settings of the two cities, as well as the vulnerabilities of both areas related to SLR. We examine and compare the management strategies being implemented to counteract the effects of the SLR in the two cities. Both cases have adopted many of the same interventions although the context varies. At the same time, we note some significant differences in adaptive strategies due to the physical settings, the administrative and political scenarios, and the social realities. Nevertheless, as two highly vulnerable coastal cities both Venice and Miami offer important lessons to other regions that also must confront SLR threats. 


\subsection{Venice}

Founded in the $5^{\text {th }}$ Century, Venice became a major medieval maritime power in the Mediterranean. Venice Lagoon houses over 100 small islands, the largest of which have been urbanized over the centuries in a unique and extraordinary architectural style that clearly deserves the designation as a UNESCO Cultural World Heritage Site. During medieval times, Venice was continuously under threat from other maritime city-states. Today Venice and its lagoon face different threats of flooding and rising sea levels, as well as unsustainable levels of tourism. The North Adriatic Sea and Venice Lagoon appear to be the most vulnerable zones to SLR in Italy, where several square kilometers of land are at or below sea level. In particular, most of the wetlands and beaches of the $\sim 300 \mathrm{~km}$ of North Adriatic coast present medium-to-high vulnerabily to inundation and flooding (Lambeck et al., 2011; Torresan et al., 2012).

In 2010 UNESCO noted that the average water level in Venice Lagoon was some $30 \mathrm{~cm}$ above the 1897 standard. Land subsidence and sea level rise are jointly responsible for higher water levels that have caused increasingly frequent flooding. The most dramatic and publicized flooding event was the disasterous event of 4 November 1966 when water levels were $1.94 \mathrm{~m}$ higher than the 1897 standard (Trincardi et al 2016). Since then high water events (acqua alta) are ever more frequent, and currently around $10 \%$ of the city is flooded 15-20 times a year. For more than a millenium, Venice has coexisted with the sea and created and adopted numerous interventions to adapt to flooding and the aqueous milieu. During the past 20 years, the region and Italian State have opted for a high tech experimental solution of mobile flood gates at the three entrances to Venice Lagoon from the Adriatic (MoSE).

\subsection{Miami}

The longevity of Miami contrasts greatly with that of Venice. The city was founded just over 100 years ago, and today over 2.6 million people reside in the metropolitan area (Miami-Dade County). While Miami lacks the architectural masterpieces of Venice, it also draws millions of tourists and in a sense is a "maritime power" due to its port which labels itself the "Cruise Capital of the World". Also similar to Venice, Miami is extremely vulnerable to flooding and rising seas. Sea levels in South Florida have increased about a foot $(30.5 \mathrm{~cm})$ since the 1930s. As global mean sea level continues to climb in the future, extreme events such as storm surges from hurricanes and tropical storms, as well as extreme ("king") tides will be superimposed on a higher base level (Kemp and Horton, 2013). Several cities in South Florida are already experiencing flooding during high tide events, as well as extreme rainfall events. Several streets on the west side of the City of Miami Beach flood about six times per year during "king tides" around the fall equinox. Furthermore, in recent times Miami area is apparently rising much faster than other places in US (Valle-Levinson et al., 2017). Using U.S. Army Corps of Engineers estimates for SLR, the Union of Concerned Scientists predicts that Miami Beach streets will flood about 380 times per year by 2045 (UCS, 2016). 
While other coastal cities (Boston, New York, Hong Kong, Guangzhou, Ho Chi Minh City, Dacca) are at risk and face greater potential economic and social losses from flooding, Venice is one of the first cities that has learned how to deal with rising seas and is among those taking the first steps to adapt to this reality. Miami has only recently become aware of its vulnerabilities but is actively addressing the threats. The two cities' adaptation measures may be effective and could have worldwide applicability. The question is "What lessons can Venice and Miami offer other coastal cities to counter the effects of rising sea levels in the next 50-100 years?" ${ }^{1}$

\section{Physical and Human Environments}

\subsection{Venice}

\subsubsection{Physical Setting}

The Venice Lagoon is part of one of the most important barrier - island system in the world; it is the largest Mediterranean lagoon and one of only two tidal coastal wetlands in the Mediterranean region (FAO, 2015). This is a complex system affected by multiple natural and anthropogenic forcing factors, and characterized by high heterogeneity in physical, biogeochemical, and biological conditions of mutually interacting habitats.

The Lagoon originated nearly 6-7 kyr BP when the rising sea flooded the Upper Adriatic Würmian paleoplain. Prior to 1500 AD, the rivers and tidal currents entering the Lagoon contributed to sedimentation in salt marshes and mudflats. A series of man-made changes between the 15th and 20th centuries (river diversions, construction of jetties at the inlets, and deeper dredging of navigation channels) have had a significant impact on the lagoonal morphology (Molinaroli et al., 2009; Sarretta et al., 2010). By 1968 more than $50 \%$ of the natural lagoon had been reclaimed or cordoned off for business-related purposes, such as construction of the industrial complex of Porto Marghera, fishfarming, and the Venice Airport (see Supplementary material, Table 1).. The reduction of the total surface of the lagoon and the modification of natural morphological features contribute to amplification the flood surge.

\subsubsection{Human Record}

Since the beginning of last century a new urban model stimulated the city's economy and extended Venice's footprint to the mainlnd. As a result, the ancient city has become a residential, tourist, and cultural centre, while the mainland (Marghera - Mestre) has evolved into an industrial, port, and commercial center. These developments created a series of interventions in the lagoon: 1) loss of vast areas of saltmarsh for land

\footnotetext{
${ }^{1}$ In 2011, Venice was chosen as a role model city for cultural heritage protection by the UN Office for Disaster Risk Reduction (UNISDR, 2009). As one media commentator noted following the 2012 Super Storm Sandy that caused damages of about $\$ 75$ billion, "The perils of Venice are real; this treasury of civilization does need protecting. But Venice has some lessons to teach about how to live with the sea, in what the Most Serene Republic always boasted was a happy marriage."
} 
reclamation, 2) the excavation of new navigation channels, 3) the modification of inlets and the construction of jetties. These interventions have caused adverse impacts on Venice Lagoon resulting in the transformation of a coastal lagoon into a bay with greater marine characteristics.

For more than 50 years through the 1970s, industries in the area pumped groundwater, a practice that - in conjunction with natural sinking from tectonic reasons - accelerated the city's subsidence of about $\sim 12 \mathrm{~cm}$ during the last century. Meanwhile, during the past century the resident population in historic insular Venice decreased from $\sim 170,000$ to $\sim 50,000$ today, with an increasing percentage of senior citizens. The opposite trend occurred on the mainland; population increased from $\sim 20,000$ to more than 180,000 . Various factors explain this demographic decline in the historic city; one of the most important is its progressive industrial decline with a consequent increase in unemployment. Moreover, due to deterioration of the housing stock, the increasing frequency of floods, as well as the relatively high cost of living, increasing numbers of inhabitants continue to move from the historic city to mainland urban centers, such as Mestre and Marghera (Favero, 2014). Nevertheless, housing costs in Venice are the highest of any Italian city - amost $\$ 5,000 / \mathrm{m}^{2}$ (Idealista, 2015).

\subsubsection{Economic Activities}

Tourism is Venice's most important economic activity, but also a major source of pollution, as well as a negative influence on the quality of life of Venetian residents. The "tourist presence" has increased from 1.5 million person-days in the 1950s to about 10 million today, with about 4 million visitors staying an average of 2.3 days. In addition, some 15-20 million of daily visitors, including some 2 million cruise tourists arrive each year, compared to around 200,000 in 1990.

Other economic activities not directly related to the historic city are the chemical industry, the modern commercial port, glassworking on Murano Island, and beach tourism (Lido and nearby barrier islands). At the end of '70s Venice became the main port of the Northern Adriatic Sea. Ship size and number progressively increased and today there are serious concerns regarding the impacts of navigation. Currently, the average number of port calls is around 3500 with 3000 through the Malamocco inlet (essentially all commercial vessels) and 500 through the Lido inlet (mostly cruise ships). The Lagoon ecosystem supports half a million wintering waterbirds, an increasing number of birdwatching tourists, and 1,600 birdhunters. More than 2,000 persons work in the Venice Lagoon as professional (traditional) fishermen, recreational fishing guides, and fish and clam farm employees.

The need for protection of Venice and its lagoon from high-water became evident after an assessment of the damage caused by the dramatic floods of November 4, 1966 (Section 1.1). That event caused US\$400 million damage to people, buildings and 
monuments and also led the Italian Legislature to approve the Special Law ${ }^{2}$ setting the stage for broad interventions to minimize the vulnerability from future floods. We describe these interventions in Section 5 of the manuscript.

\subsection{Miami-Dade County (Southeast Florida)/Biscayne Bay and Barrier Islands}

\subsubsection{Physical Setting}

The southeast portion of the Florida Peninsula is comprised of a nearly level plain (average elevation $2 \mathrm{~m}$ ). On the east side landforms include the shallow Biscayne Bay and the barrier islands of Miami Beach, Virginia Key, and Key Biscayne, with elevation ranging between $1.5 \mathrm{~m}$ and $3.5 \mathrm{~m}$ above MLW. The bedrock in Miami-Dade County consists of Quaternary (Pleistocene) oolitic limestone and fossiliferous limestone. The limestone that forms the Florida Peninsula became exposed to air and rainwater during glaciations resulting in partial dissolution. South Florida's limestone bedrock is, therefore, very porous and highly permeable and today holds the surficial Biscayne Aquifer. The porous nature of the fossil limestone substrate becomes an important consideration with SLR.

Biscayne Bay occupies a shallow limestone depression east of mainland extending some $48 \mathrm{~km}$ north to south with widths of up to $13 \mathrm{~km}$. The bay is shallow with natural depth in the center of 2 to 4 meters above MLW. Limestone bedrock and carbonate muds form the bottom of Biscayne Bay (Hoffmeister, 1982). The central and southern bay has natural shallow openings to the Atlantic unlike the more isolated northern Bay. Freshwater delivery to Biscayne Bay occured naturally through some 12 transverse glades, diffuse freshwater flow, and groundwater (Biscayne Bay Aquifer) (Lodge, 2010; Hoffmeister, 1982; Obeysekera et al., 1999).

North Biscayne Bay has been extensively modified during the past century. Two inlets have been opened to the Atlantic. Most of the fringing mangroves have been removed, filled, and bulkheaded for residential development. Numerous artificial islands were created with the dredge spoils (see Supplementary material, Table 2).

Serious alteration of freshwater delivery to Biscayne Bay began in 1948 with the approval of the Central and Southern Florida Project for Flood Control (Grunwald, 2007). This major insfrastructure project constructed a series of levees and canals that block sheet flow to Biscayne Bay and reduce risk of flooding opening vast areas of the county to residential development. The diffuse flows and trans-glade wetland flows have been changed to point sources with the construction of some 19 drainage canals that are opened and closed in manners to avoid flooding and saltwater intrusion into the Biscayne Aquifer. As a result of the levee and canal system, Biscayne Bay has lost many

\footnotetext{
2 The Special Law ("New Interventions for the Protection of Venice”, Law no. 789 of 29 November 1984) implied that the Veneto Region, the Venice and Chioggia municipalities, and the Commission to Protect Venice were all to be involved in the management of the lagoon.
} 
of its estuarine functions and has generally become much more saline. Large releases of freshwater from the drainage canals result in sharp salinity changes (Lodge, 2010).

The barrier islands of Miami Beach, Virginia Key, and Key Biscayne in north and central Miami-Dade County parallel offshore coral reefs tracts and linear exposures of coralline limestone bedrock on the seafloor. In the second decade of the 20th Century these barrier islands were built up with dredged material from Biscayne Bay (Goodell, 2017). Bulkheads were built on the bay side of Miami Beach at the same time.

The South Florida peninsula contains the only subtropical climate in the US mainland (Corcoran and Johnson, 2005), and region is highly vulnerable to tropical storms and hurricanes in the late summer/early fall (Duever et al., 1994). Since 1871, some 44 hurricanes have struck South Florida (approximately one event every three years) (Lodge, 2010; Gamio, 2016). These tropical cyclones bring rain, wind, high ocean waves, and storm surges to the region - all which may cause serious impacts to the infrastructure, ecosystems, and the coastline. In this low elevation region, storm surges can potentially be disastrous. For example, Hurricane Andrew that struck the southern region of Miami-Dade County in August 1992 produced a storm surge of up to 5.2 meters above regular tidal levels.

\subsubsection{Human Record}

Miami's growth over the past century has been explosive. The city's modern history only began in 1896 with the arrival of the Florida East Coast Railway that brought tourists from the northern US and spurred land speculators and developers. From a population of 4,955 persons in 1900, Miami-Dade County's (formerly "Dade County") population had increased ten times by 1920 to 42,753 persons; 142,955 persons by $1930 ; 267,739$ residents by 1940 , and 488,689 by 1950 . This phenomenal growth was perhaps due to exposure of the region to troops training there during World War II, as well as to the availability of lands recently reclaimed from the Everglades wetlands ecosystem. The population again saw a significant increase after the 1959 Cuban Revolution with the influx of hundreds of thousands of political and economic refugees. As a result, of its "latinamericanization", the county has become an important commercial, financial, and transportation link between the USA and Latin America. By 2000, the county's population had exploded to 2,253,362 residents (Miami-Dade County, 2009). By 2010, the county's population had surpassed 2.5 million people, and over 6 million people called southeast Florida home.

The City of Miami Beach, located on the barrier island of its name, is the county's icon beach destination with average elevation only 1.3 meters $(4.4 \mathrm{ft})$ above MSL. Incorporated in 1915, Miami Beach housed about $10 \%$ of the county's population until about 1950. The population peaked in 1980 at 96,298 with many of the Cuban refugees from the Mariel Boatlift finding residence in that City. Since that time, the Miami Beach population has decreased slightly toward the present level of 87,779 (Suburban Stats, 2018). The smaller barrier island of Key Biscayne to the south of Miami Beach, 
incorporated in 1991, has a current population of 12,344 persons (Suburban Stats, 2018). It, also, sits barely above the sea with average elevation 1 meter ( $3.4 \mathrm{ft}$.) above MSL.

\subsubsection{Economic activities}

The principal_economic activities in Miami-Dade County today are tourism, real estate development, financial services, and international trade with transportation hubs that are the Port of Miami and the international airport. Tourism is the primary economic industry in Florida, and the State received about 90 million visitors in 2012 (Seccombe, 2013). Miami-Dade County is one of the State's primary tourist destinations accounting for about 30 percent of the $\$ 71.8$ billion that visitors to Florida spend each year. South Florida's beaches and nearshore and coastal environments are the principal attraction for tourists. Miami Beach attracted over 7 million overnight visitors in 2015 who spent almost $\$ 12$ billion during their stay. During that same year, Miami-Dade County hosted 15.5 million overnight visitors who spent $\$ 24.4$ billion.

In 2016 the total value of taxable properties in Miami-Dade County reached $\$ 250$ billion. This was an $8.6 \%$ increase in value over the prior year - largely fueled by new construction that was responsible for $\$ 5$ billion in new taxable property values. According to the County's Property Appraiser, the total property value in the City of Miami Beach was assessed at almost \$35 billion in 2016, a 12.2\% increase from the previous year. New construction accounted for $\$ 1.156$ billion in property values in that municipality (Stewart-Muniz, 2016). Today construction and property values in the county are booming and have recovered from the 2007 financial crisis in the more affluent areas of the county (Brannigan, 2014).

\subsubsection{Port of Miami and International Trade}

With the establishment of downtown Miami at the end of the 19th Century came the need to develop a port and improved access to the Atlantic Ocean. Government Cut navigation channel was dredged across the southern tip of Miami Beach to $5 \mathrm{~m}$ depth during the first decade of the 20th Century. A little more than a century later, the Port of Miami has evolved into a major US port specializing in container and passenger traffic (Melick, 2010). The Port of Miami estimates its annual contribution to the local economy to be $\$ 41.4$ billion and its activities directly providing almost 22,000 jobs (Miami-Dade County, 2017b). Containerization of the Port of Miami began with construction of Lummus Island that involved additional dredging of the navigation channel and fill of Biscayne Bay in the 1980s. The first large contained vessel called at the Port in 1987 and the first panamax container ship, in 1993. A recent port expansion project ("Deep Dredge"), completed in 2015, dredged Government Cut and nearby port areas to 15 meters permitting post-Panamax containerized vessels to enter the port. The Port of Miami hopes to capture US-bound East Asian maritime traffic that is now able to pass through the newly widened Panama Canal locks. By the mid-1970s, three cruise ship lines had begun calling at the Port of Miami. The Megaship Era of the Port of Miami began in 1988 with the arrival of a new generation of cruise ships. Today Miami is known as the "Cruise Capital of the World" with over 5.3 million cruise tourists boarding at the port in Fiscal Year 2016-2017 (Miami-Dade County, 2017a). 


\section{Methodology}

Our analysis utilizes both archival and observational methodologies as well as interviews and discussions with government officials, representatives of environmental and civic groups, and natural and social scientists.

Moreover, the authors are researchers in both cities who are closely involved in SLR adaptation issues. The list of people interviewed and documents examined can be found in Supplementary material.

The two countries represent distinct cases in relation to the extent of their engagement with planned adaptation. Venice was one of the first European cities to adopt a hightech adaptation project (Suman et al., 2005) and an associated national and regional implementation plan, complemented by other adaptation actions within various municipalities. On the contrary, Miami has adopted widespread strategies, both for beach management and in response to floods (Ariza et al., 2014). Within each country, different administrative units were examined to represent areas where interest and action in adaptation were high

\section{Political-Administrative Environments}

\subsection{Venice}

Many different institutions possess administrative and technical competence to deal with problems related to climate change in Venice. Among these are Italian governmental agencies at the State (National), Regional, Provincial, and Municipal levels, as well as UNESCO. Ideally, institutional coordination should support effective management Vencie Lagoon in light of threats. Constant change presents additional management challenges, a reality examined by both Suman et al. (2005) and Munaretto and Huitema (2012). Suman et al. (2005), studied the Venice Lagoon and its watershed with reference to integrated coastal management. Those authors argued that - at that time - public participation and area-based management was often neglected by administrative bodies involved in the planning of coastal projects and public works. Their analysis highlighted a substantial absence of coordination among the various administrative bodies in charge of planning and management at various governmental levels and in different regulated economic sectors. More recently, Munaretto and Huitema (2012) have analyzed water and environmental management in the Venice Lagoon and have concluded that the existence of the Special Law no. 789 on 1984 inhibits participation and real polycentricity, making it difficult to change policy and tackle problems on a bioregional scale. The authors suggested "adaptive comanagement" as a way to manage the modern challenges of environmental governance, including uncertainty.

The present situation has become critical, due to issues of corruption and the permanent lack of coordination between the bodies responsible for managing the lagoon. Moreover, in the last two years some administrative bodies have been changed 
or eliminated, and a new administrative entity has appeared: the Metropolitan City. A description of the principal actors continues.

"Provveditorato Interregionale alle Opere Pubbliche per il Veneto, Trentino Alto Adige e Friuli Venezia Giulia", a branch of the national Ministry of Infrastructure and Transport, is responsible for pollution abatement and maintenance in the lagoon, as well as flood defenses. It has replaced the Venice Water Authority (VWA) which was eliminated in June 2014, and its projects are largely implemented by its concessionary, the powerful Consorzio Venezia Nuova (CVN), a group of Italy's leading industrial companies and local firms, that researches, develops, and executes measures to protect Venice from flooding. The Consorzio is currently under controlled administration due to charges of managerial corruption. The Consorzio's current mandate comes to an end in 2020-21 when MoSE should be completed. No plan exists for a replacement entity.

Eastern Alpine Basin Authority. The Italian territory has been subdivided into seven Districts, and the watersheds of the Northeast have been united in the Eastern Alps District, whose boundary substantially coincides with the past territorial competences of the VWA. In 2016 the Basin Authority approved an updated Water Management Plan and the Flood Risk Management Plan. These Plans, in line with the Regional Water Protection Plans, refer to all the water bodies (surface, underground, transitional, coastal) of the Hydrographic District, and a relevant part includes the "Hydrographic Subunit of the Watershed, Venice Lagoon and Adjacent Sea".

The Veneto Regional Government is responsible for pollution abatement in the lagoon's drainage basin, tourism and transport on the mainland, landscape, and some aspects of navigation. In 2016 it released a document that identified areas at greatest risk from flooding considering different climate change scenarios (Veneto Regional Government and the University of Padova, 2016). The Regional Government's plan highlights the MoSE Project as adaptative interventions at the three lagoon inlets.

The recently created Metropolitan City of Venice will take over some of the responsibilities of the communes around the lagoon and the Province ${ }^{3}$ (previously responsible for some environmental aspects on the mainland and fisheries in the lagoon). This new institution should assert authority over the Lagoon and MOSE. The Metropolitan City could provide an opportunity for more integrated decisionmaking. However, the institutional creation of the Metropolitan City is proceeding slowly.

In 1987, Venice was declared a UNESCO World Heritage Site, and consequently, Italy agreed to produce a management plan and define a "buffer zone" around Venice. By November $2012^{4}$, the plan for Venice was finally approved by the City Council.

\footnotetext{
${ }^{3}$ The Province in 2008 prepared a Flood Plan ("Piano Mareggiate") with a management geodatabase of the Venetian coasts containing all geomorphological data.

${ }^{4}$ http://www.veniceandlagoon.net/web/wp-content/uploads/2014/12/MP_volume_low_eng.pdf
} 
Development of the 157-page plan required more than 20 years, based on consultation with 250 public bodies that suggested 136 proposals. The document was judged to be very poor and ignored many significant issues, such as big ships, unsustainable tourism, and the decline of residents. The most significant gap in the management plan was its failure to consider SLR. Of course, the plan mentions flooding and MoSE, due to be completed at that time by 2018 , but SLR is only superficially mentioned. In 2015 , UNESCO warned that Venice might be included in the list of UNESCO World Heritage Sites In Danger if Italy had not banned large cruise ships from the city's lagoon by $2017^{5}$.

The Venice Port Authority, a national entity, is responsible for shipping channels across the lagoon, the Giudecca Canal through Venice, and the ports in Venice and around the lagoon. The Port Authority would like to be involved in the MoSE management because of its direct impacts on navigation.

Rusconi (2016) analyzed the problems related to lagoon management after the 2014 elimination of the Venice Water Authority (VWA), arguing that it was inappropriate to define the tasks of the eliminated VWA only related to Venice Lagoon, neglecting the overall hydraulic and maritime contexts. Ecosystem-based management of the waters of the "Hydrographic Sub-unit of the Watershed, Venice Lagoon and Adjacent Sea" is required, according to the Management Plans drawn up by the Eastern Alpine Basin Authority and implemented by the Veneto Regional Administration. The absence of a coordinating body, potential conflicts between a new Special Law now under discussion and European Directives (Water and Floods), and the potential transfer of overall management to the Metropolitan City of Venice are issues of uncertainty and great concern.

\subsection{Miami}

Miami's administrative framework is less complex than that of Venice and is divided between the national (federal) government, the State of Florida, Miami-Dade County and its municipalities. While perhaps less complex, the US situation remains challenging and vertically fragmented.

The federal government appeared to be moving toward action to address climate change during the Obama Administration. In February 2013, Federal agencies released their first Climate Change Adaptation Plans. Obama's June 2013 President's Climate Action Plan summarized federal agency policies to address climate change issues. Key among the identified efforts was the development of partnerships between federal agencies and local governments to assess vulnerability to infrastructure and identify solutions that reduce risks. Federal efforts would support community-based efforts to prepare to climate change and enhance resilience via federal grants and technical

\footnotetext{
${ }^{5}$ In 2018 the large vessels, with a maximum limit of 90,000 tons, still enter the lagoon.
} 
assistance. However, the Trump administration that assumed power in January 2017 has retreated from numerous climate change initiatives (Davenport, 2018).

Despite these policy shifts from the Executive, numerous federal agency programs do have direct relevance to sea level rise and flooding. Of particular significance are the programs of the US Army Corps of Engineers (USACE) and the Federal Emergency Management Agency (FEMA). The USACE is responsable for developing infrastructure that protects against flooding. Section 404 of the Clean Water Act also grants the USACE permitting autority over activities that discharge dredge or fill materials to waters of the United States. Mandated by this legislation, the USACE carries out planning and funding of regional beach renourishment projects. As part of its National Flood Insurance Program (NFIP), FEMA is charged with flood plain mapping and administering the NFIP that provides subsidized flood insurance to property owners whose communities comply with FEMA flood plain standards. The current flood plain maps prepared by the FEMA became effective in September 2009. Miami-Dade County adopted the maps in July 2009 in satisfaction of the requirement for the county to participate in the National Flood Insurance Program. Structures located in flood plain zones $A, A H, A E$, and VE are eligible for subsidized flood insurance. Zones $A H$ (flood depth from 0.3 to $0.9 \mathrm{~m}$ ) and $A E$ (flood depth greater than $0.9 \mathrm{~m}$ ) have a moderate to high flood risk. Flood risk is high in Zone A ( 1 in 4 chance of flooding during 30 years) and Zone VE ( 1 in 4 chance of flooding during 30 years with additional hazards due to storm waves). However, the flood plain maps are based on historical data, are not proactive and do not currently consider SLR. A lively current issue is whether the NFIP should increase its rates to better reflect the risks.

Despite Florida's high vulnerability to climate change impacts, at the State level, planning for response and adaptation to climate change is not directly addressed. In a 2012 evaluation of states' preparation planning for climate change, the Natural Resources Defense Council (NRDC) ranked Florida in Category three out of four categories; the 29 states in Categories three and four are "largely unprepared and lagging behind" (NRDC, 2012). The NRDC Report stressed the importance that the Governor has in planning for climate change- "without a top-down directive from the executive level, there is unlikely to be sufficient action by all necessary government agencies within a state on climate change issues." Recent responses to climate change impacts from the Governor of the State of Florida have not been energetic. The current Governor Rick Scott, a Republican who was first elected in November 2010 and remains skeptical about climate change claiming not to be a scientist, has established an unwritten policy that State of Florida agencies not use the phrases "climate change" and "global warming" in their documents. Reports of this policy come from Florida's Department of Environmental Protection, the Department of Transportation, the Department of Health, and the South Florida Water Management District (Korten, 2015).

At the regional government level, the Southeast Florida Regional Planning Council (SEFRPC) is a four county (Palm Beach, Broward, Miami-Dade, Monroe) planning agency 
that recommends regional plans and advises counties on specific development projects. As we discuss below, the SEFRPC adopted the Southeast Florida Regional Climate Action Plan in 2009 that laid out numerous recommendations for counties in areas of climate change adaptation and mitigation.

The local government is led by strong Miami-Dade County Mayor and Board of County Commissioners with authority over schools, water and sewage, and land use planning. Governance is shared between the Miami-Dade County government and some 35 muncipalities, as well as incorporated areas. Municipalities are responsible for zoning, code enforcement, police, and fire protection. Miami-Dade County has developed the County Comprehensive Development Master Plan (CDMP) and an Miami-Dade County, Florida Comprehensive Emergency Management Plan prepared in 2017. The CDMP lays out policies and objectives for development, land use, and natural resource use for the next 10-20 year period and then describes the means that the County will adopt to meet the objectives and deliver its services. The Board of County Commissioners has adopted Land Use Maps 2020-2030.

Miami-Dade County's Office of Resilience assesses vulnerabilities and forges collaborations with county agencies, other levels of government, and stakeholders to promote environmental sustainability. The Office of Resiliency has coordinated the development in 2014 of the County's first Climate Action Plan that addresses mitigation measures to reduce greenhouse gas emissions and measures to adapt to climate change impacts (Miami-Dade County, 2014a). As we will mention below, some of the County's municipalities have also developed climate action plans.

\section{Vulnerabilities}

Vulnerability and resilience have been discussed several decades (Klein et al., 2003; Turner et al., 2003; Wisner et al., 2004; Adger, 2006; Cutter et al., 2008; Birkmann, 2006; Borg et al., 2014; Varrani and Nones, 2017) although concrete definitions and conceptualization vary. The climate-related hazards in coastal areas are primarily attributable to the combined effects of SLR and local features, such as subsidence, storm frequency and associated storm surges, and the value of infrastructure in coastal areas susceptible to flooding and SLR. We will examine the two cities' vulnerabilities and then compare their adaptive strategies.

Vulnerability is the lack of a system's capacity to deal with a natural hazard (UNISDR 2009), while resilience is a system's ability to anticipate, prepare for, and adapt to changing conditions and withstand, respond to, and recover rapidly from unexpected events that may occur (NAS, 2012). The ability of a system to mitigate stresses or cope with the consequences through various strategies constitutes a key determinant of system response and, ultimately, impact (De Sherbinin et al., 2007). Floods occur periodically both in Venice and Miami. Although they have different geological and 
historical realities, they share some common features that allow comparison their vulnerabilities and adopted adaptative policies.

\subsection{Venice}

Venice has literally sunk almost $25 \mathrm{~cm}$ during the last century. The combined result of natural subsidence of about $10 \mathrm{~cm}$ throughout the northern Adriatic, accelerated by the pumping of groundwater and natural gas extracted from the area from 1930 to 1970, and SLR resulting from climate change are contributing factors. Subsidence has accelerated in recent years. Teatini et al. (2012) found that during the period 1992-2007, some parts of the southern lagoon margin subsided up to $5 \mathrm{~mm} \mathrm{yr}^{-1}$; major changes were probably related to the infrastructure works built for shoreline reinforcement. Tosi et al. (2014) quantified the relative land subsidence occurring during 1992-2010 along the Venice coast, showing a high variability of the relative land subsidence, with values of 20-140 mm on a regional scale and up to $200 \mathrm{~mm}$ locally._Subsidence of the lagoon has increased the frequency of flooding events (acqua alta) and favored sediment erosion (Fagherazzi et al., 2006), the loss of finer sediment (Sarretta et al., 2010) and the increasing influence of marine processes (Fagherazzi et al., 2006; Sarretta et al., 2010).

Antonioli et al. (2017) projected the relative sea level change along the coastline of the North Adriatic by 2100, as well as flooding risk scenarios for Venice Lagoon. They utilized three scenarios of expected SLR, of 0.53, $0.97 \mathrm{~m}$ (IPCC 2010, min and max) and $1.4 \mathrm{~m}$ (Rahmsthorf, 2007) and calculated the extent of flooded areas (Fig. 1). The lower SLR will flood more than $30 \%$ of the historic city, while the worst scenario will affect more than $85 \%$ of the city. Moreover, they hypothesized that the combination of SLR and possible decrease of rainfall will produce a negative sedimentary budget and significant shoreline retreat.

Estimates of shoreline retreat on the barrier islands of Lido and Pellestrina range from 18-75 m, under two different SLR scenarios of 40 and $85 \mathrm{~cm}$ for years 2050 and 2100 respectively (MAV-CVN, 2013). Because barrier islands buffer the mainland coastal areas from storm surge and ocean wave energy, changes in their shape or partial disappearance due to erosion may lead to a reduced protection of the Lagoon and Venice (Ramieri et al., 2011). In addition, sand loss can cause significant economic impact because tourists utilize most of the beaches. 


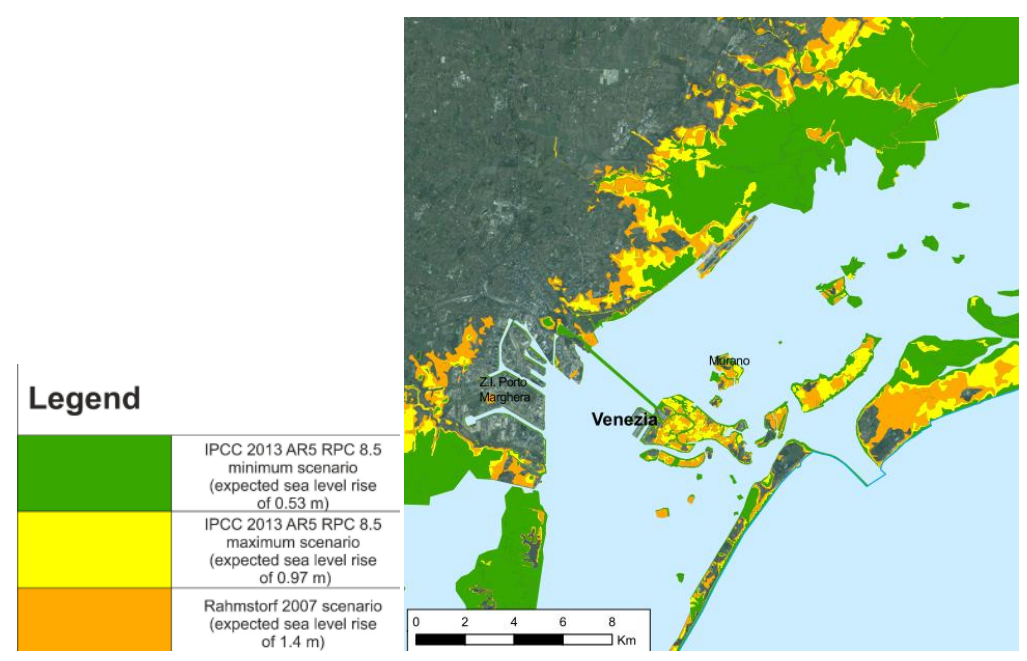

Figure 1. Flooding scenario of lands adjacent to the Venice Lagoon using three relative SLR models (adapted from Marsico A. et al., 2017. Flooding scenario for four Italian coastal plains using three relative sea level rise models, DOI: https://doi.org/10.6084/m9.figshare.5766519.v1)

Torresan (2012) presented a Regional Risk Assessment (RRA) methodology for the integrated assessment of the impacts of climate change in coastal areas. In particular, the RRA was applied for the assessment and definition of the priorities of targets and areas at risk in relation to possible SLR and the impacts of erosion, considering a scenario of climate change for the period 2070-2100 in the coastal area of the North Adriatic. Rizzi et al. (2017) assessed storm surge risk under different SLR scenarios and identified hot spot risk areas in the North Adriatic coast and targets requiring particular attention for the definition of adaptation startegies. Those authors considered, among others, a worst scenario of SLR of $42 \mathrm{~cm}$ for the year 2100; in that case, more than $90 \%$ of the beaches would experience higher risk. Similarly, coastal wetlands, expecially those around Venice and those of Marano and Grado, were classified as areas with elevated risk.

\subsubsection{Economic Consequences of Climate Change}

Significant efforts have been made to estimate the costs of rising sea levels and temperature increases in the Adriatic Sea, particularly in the Venice city. The impacts of climate change on coastal tourism, focusing on the historical center of Venice, for example, have been estimated at a loss of $€ 35-40$ million in 2030 . Similar estimates have been made for the clam aquaculture, focusing on the most important areas of the Venice Lagoon in terms of productivity (a loss of $€ 10-17$ million in 2030). Flooding from SLR in Venice may result in loses to economic activities of perhaps more $€ 100$ million $n$ 2030 (Carraro and Sgobbi, 2008). Vergano et al. (2007) calculated damage estimates ranging between $\$ 10$ and 30 million for each of the 15 exceptional high tide events (over $140 \mathrm{~cm}$ ) that have occurred since 1966 onwards. 


\subsection{Miami}

Miami's setting makes it highly vulnerable to flooding. It is a low-lying region with porous limestone substrate and high water table. Its urbanized barrier islands are exposed to Atlantic Ocean. The entire region has high exposure to hurricanes and tropical storms. All these realities increase the risk of flooding and limit the effectiveness of adaptation measures, such as seawalls, replenished beaches, pumps, levees, and sea closure gates.

A recent World Resources Institute report focused on the State's four southeastern counties (Monroe, Miami-Dade, Broward, and Palm Beach) that are the most urbanized, have the highest population concentration in Florida (almost 6 million persons in the four county area), and only lie several meters above sea level. Miami-Dade County with 2.6 million residents has more people living less than 1.3 meters above sea level than any state except Louisiana (and of course, Florida itself). About 25 percent of the county's land is less than one meter above sea level. Evaluations of cities most vulnerable to losses from flooding rank Miami in sixth place of global cities and first place of U.S. cities (Ghose, 2013).

Not only does Miami-Dade County have a large population, but its growth has been explosive during its 120 year history. This fast growth rate has presented challenges for comprehensive land use planning. Despite increased acceptance of the region's vulnerabilities, high rates of growth continue. Property values continue to increase despite SLR threats and even the 2017 experience of Hurricane Irma. Florida's lack of state income tax means that Miami-Dade County has a high dependence on local property taxes for its budget. This reality tends to lubricate willingness to approve permits for new construction.

Since 2006, Miami Beach has experienced a SLR of $9 \mathrm{~mm}$ per year (Wdowinski et al., 2016; Treuer et al., 2018). Assuming similar rates in the future and no adaptation measures, a SLR of 0.5 meter by 2070 could threaten assets of $\$ 3.5$ trillion in MDC and displace 300,000 persons (Hanson et al, 2011; Hauer et al., 2016, Treuer et al. 2018). Rao (2016) suggests that a 2 meter SLR could result in lost home values of $\$ 400$ billion in Florida by 2100 . An intermediate SLR range predicted by NOAA for 2050 could result in annual flood losses of $\$ 25$ billion (Sweet et al., 2017; Treuer et al., 2018). Assuming population growth, moderate SLR rates, and implemented adaptation measures, losses from flooding in Miami may still increase to $\$ 2.55$ billion by 2050 (Hallengatte et al., 2013; Kulp and Strauss, 2017).

In addition to Miami's vulnerability to SLR, the region also has high exposure to hurricanes and associated storm surges, as well as high rainfall events. Of the Category 3 to 5 hurricanes that made landfall on the Atlantic Coast of the U.S. between 1851 and 2008, some 39 percent struck Florida (AOML, 2009). On average from 1900 to 2007 a 
hurricane struck Florida once every two years, and a strong hurricane, every four years. Eight of the ten most expensive hurricanes in the U.S. have affected Florida. Hurricanes bring high winds, storm surges, high energy wave action, coastal flooding and erosion, loss of coastal wetlands, and saltwater intrusion. Many experts predict that global warming will increase the size and intensity of hurricanes. Increased storm intensity compounded with Florida's rapid coastal development, population increases, and SLR suggest that potential losses to property from tropical storms will be extremely high. Figure 2 illustrates the projected impact of flooding in MDC taking into account both SLR and the storm surge generated by a Category 3 hurricane.

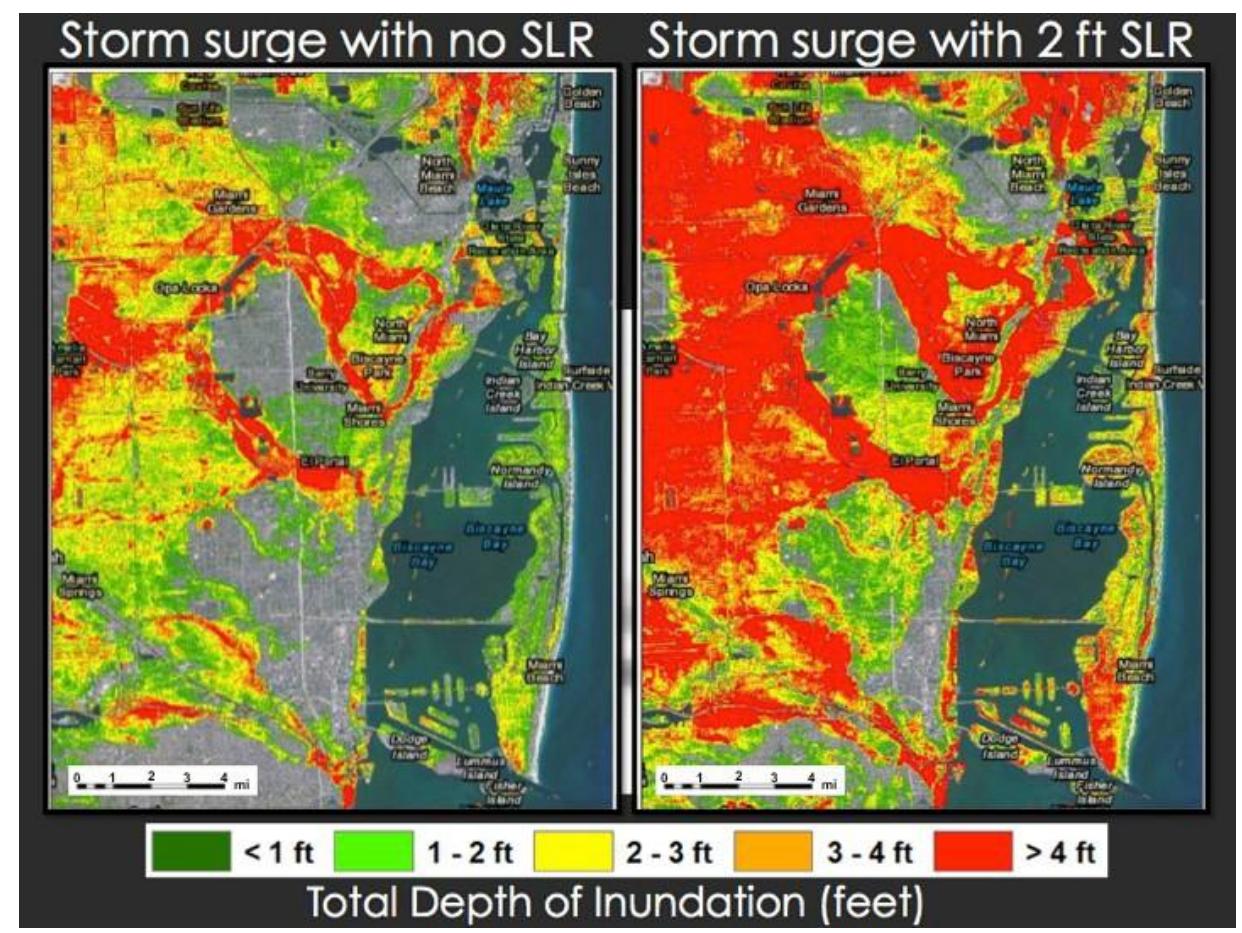

Figure 2. The map on the left indicates depth of flooding in MDC from a storm surge associated with a Category 3 hurricane with no SLR. The map on the right indicates depth of flooding in MDC from a storm surge associated with a Category 3 hurricane and SLR of 2 feet (Miami-Dade County, 2014. Miami-Dade Sea Level Rise Task Force report and recommendations. Figure 2. Available at:

http://www.miamidade.gov/planning/library/reports/sea-level-rise-reportrecommendations.pdf.).

\section{Adaptation Management}

Adaptation to climate change is essential to manage present risks and potential for more serious future changes, and has entered the planning agenda of many cities around the world (Araos et al. 2016; Juhola and Westerhoff, 2011). With improvements in high-resolution modeling, it is possible to map the expected SLR in specific locations (LiDAR), both worst-case and expected-case scenarios. In many locations this very detailed awareness of vulnerability leads to proactive planning and mitigation actions 
(De Sherbinin et al., 2007). Disaster preparedness and management plans are vital components of an adaptation strategy. Venice and Miami are both struggling to maintain their environment and economic activities and, even with different scales and drivers, they are both among the most vulnerable areas to flooding caused by climate change (Hauer et al., 2016; Antonioli et al., 2017). This section describes some adaptation measures that Venice and Miami have implemented to mitigate risks.

\subsection{Venice}

Venice has a long history of adaptation to flooding. Early Venetians developed technologies to build on the water, construct firm foundations, and raise the height of buildings (Mancuso, 2014). Archaeologists have found signs that ancient Venetians gradually raised the ground level as high as $\sim 2 \mathrm{~m}$. In St. Mark's Square, the lowest point of Venice, there are five levels of older pavement beneath today's plaza (Keahey, 2002). The inhabitants of Venice diverted the lower course of the rivers in order to shape the city to their needs (Caniato, 2005). In 16th and 17th Centuries city planners actively made alterations within the lagoon and surrounding environment, including building canals to help facilitate shipping and further river diversions, as well as constructing sea barriers. During the 18th Century, work continued to improve navigability, and at the barrier island of Pellestrina, the "murazzi" (walls made of cemented rocks) were constructed to form barriers against the sea.

Several adaptation measures were put in place in Venice to counteract the flooding events, especially after the "big flood" of 1966. They can be subdivided in widespread interventions and the mega-technical barrier system, first proposed in 1981 and funded through the Special Law no 789 of 1984. In addition, the city is constantly confronted with the problem of acqua alta, flooding that occurs mainly in the winter as a result of convergence of high-tides and a strong southern Sirocco wind. Apart the "normal" high water during the last 20 years, nine "exceptional" events $(>140 \mathrm{~cm})$ have occurred, during which $\sim 90 \%$ of the city surface and more than half of the public space dedicated to pedestrian use have been inundated. The resulting consequences for people, economic activities, and buildings are considerable.

To allow pedestrian mobility around the city at high tide, a network of walkways is installed along the main pedestrian routes, generally at $\sim 110 \mathrm{~cm}$ above the standard sea level. Today flood information is provided by alarms and in real time via web and smartphone, and some public transport lines are diverted to alternative routes. Seawalls and public paved areas in the lowest lying zones are being raised to defend the city against the most frequent floods. Plans exist to raise other low-lying areas to defend against tides up to at least $+110 \mathrm{~cm}$. Among the non-structural measures for prevention, preparedness and response, Venice also counts on the strong awareness of its citizens and on their ability to adopt adaptation measures to protect their assets, particularly the cultural heritage of the city. Examples of these types of measures are the protection 
and improvement of ground floors, adaptation of electrical systems, and placement of steel barriers at the entrance to buildings (Indirli, 2014).

The following interventions stem from the 1984 Special Law no. 789: 1) restoration of the seriously damaged murazzi (seawalls) beginning in 1990; 2) nourishment of eroded beaches; 3) prohibition of methane extraction and drilling of new artesian wells; 4) elevation of low-lying parts of the urban center; and 5) dredging of internal Venice canals.

The centerpiece of the Special Law was MoSE (an acronym for Modulo Sperimentale Elettromeccanico or Experimental Electromechanical Module), begun in 2003 and expected to be completed no sooner than 2020-2022. The mobile tidal barrier project will prevent flooding through the installation of 78 mobile gates, laid at the bottom of the seabed at the three inlets - Lido, Malamocco, and Chioggia - separating Venice Lagoon from the Adriatic Sea. The manufacturers of the barriers claim that the system is designed to withstand a hypothetical average rise in sea level of $0.6 \mathrm{~m}$ and a tidal fluctuation of $3.0 \mathrm{~m}$. The mobile gates are $28 \mathrm{~m}$ long, $20 \mathrm{~m}$ wide, will weigh 300 tons, and are placed at the bottom of inlet channels supported by $38 \mathrm{~m}$ long steel and concrete pilings driven into the lagoon bed and measuring $0.5 \mathrm{~m}$ in diameter and $20 \mathrm{~m}$ in length. Compressed air is pumped into the metal-box structure when tidal events exceeding $110 \mathrm{~cm}$ are projected, protecting the city from extreme flooding. The air will raise the barriers to the water surface blocking the tidal flow and preventing water flow into the lagoon. Floodgates are hollowed at the bottom, to allow compressed air to be blown in. When there is no risk of flooding, the mobile gates will be filled with water and lowered into the seabed. Floodgates at each inlet will function independently depending on the force of the tide expected. Since 2003 the majority of funding has been dedicated to completion of the MoSE project ${ }^{6}$. Measures that previously had been implemented, such as wetland creation and beach nourishment, were halted for lack of funding.

Strong debate has surrounded MoSE since its conception regarding its effectiveness and high cost (Ammerman and McClennen, 2000; Kaluarachchi, 2014). In their analyses of changes in the dynamics of the Venice Lagoon due to the construction of the MOSE, Ghezzo et al. (2010) suggest that the mobile barriers will produce changes in the structure of the lagoon inlets, with consequences for the dynamics of the lagoon ecosystem as a whole. In particular, the most intense currents may create risks for habitat conservation in the northern lagoon, while the micro-circulation between the breakwater and the coast may trap pollutants or suspended sediments in the southern lagoon area.

\footnotetext{
${ }^{6}$ In the period 1992-2004 the average amount of annual funding of the Special Law dedicated to Venice was $€ 143$ million, reduced to $\sim 20$ million in the period $2005-2014$.
} 
Vergano et al. (2010) provided an estimate of the direct costs of the interruption of ship traffic due to the operation of the MoSE, resulting from longer waiting times for ships crossing the Venice Lagoon. Data of ship traffic in the period 2000-2002 indicated an additional annual cost of $€ 1.3$ million, but with updated traffic data, impacts would be around $€ 10$ million/year. Umgiesser and Maticchio (2006) showed that the interference with the ship traffic was acceptable under actual conditions but would become prohibitive with a sea-level rise of $50 \mathrm{~cm}$, when nearly two-thirds of the ship passages would be blocked or delayed. The same authors calculated that with SLR, the gates will be closed ever more frequently, thus reducing the survivability of marshes. Furthermore, the increasing number and frequency of closure events elevate environmental degradation, particularly water quality (UNESCO, 2011). Panza et al. (2014) have suggested that a potential seismogenic source located inland near Venice might generate a tsunami wave that could affect the MoSE gates if they are standing up (closed) during the tsunami event.

While new defense technologies have the potential to reduce vulnerability and diversify management tools, technical solutions are not necessarily the panecea. Rather, it is necessary to integrate the best technical measures into a strategic context that also considers the environmental, social and economic issues raised in any coastal area (Zanuttigh, 2011). The lagoon is a continuously evolving system that responds rapidly to human activities. As such, the long-term health and viability of this important system is contingent upon sound and effective coastal area management that should be an outcome of an integrated vision and a participatory and adaptive approach (Suman et al., 2005). Given the complex nature of how ecosystems function, great care is required in planning any intervention. While the MoSE infrastructure should protect the city infrastructure, serious questions arise whether it is beneficial to the lagoon ecosystem, the morphological evolution of coast, and the broad range of Venice Lagoon uses and resources. We question whether Venice and its lagoon will be more resilient to exceptional high tides after the MoSE barriers are completed in 2020-2022.

\subsection{Miami}

In Miami initiatives to respond and adapt to climate change and sea level rise originate primarily at the local level and are relatively recent. Florida's counties and municipalities have taken the lead in climate change preparation. The County Commissions of the four southeastern counties (Broward, Miami-Dade, Monroe, and Palm Beach) approved the Southeast Florida Regional Climate Change Compact (SEFRCCC) in January 2010 to create a united front to face regional climate change. Since then, the SEFRCCC Steering Group has adopted consistent methodologies and assessed the vulnerabilities from sea level rise in the four county region based on one, two, and three foot $(0.3,0.61$, and 0.91 meter) increases in sea level. In October 2012, the SEFRCCC produced a Regional Climate Action Plan with 110 Action Items related to reduction of greenhouse gas emissions, water supply systems, sustainable communities, transportation infrastructure, and emergency management that decision-makers at the county and 
municipal levels can adopt to mitigate and adapt to climate change (Southeast Florida Regional Climate Change Compact Counties, 2012). Although it will take many years to adopt and implement the recommendations, these are important initial planning steps.

The Regional Climate Action Plan (RCAP) recommended that municipalities and counties develop policies and standards to improve resilience to coastal and inland flooding, saltwater intrusion, and other impacts from climate change and sea level rise and include these in their planning documents (Comprehensive Development Master Plans, Adaptation Action Area Plans, Sustainability Plans, Climate Change Plans, etc.). The RCAP also encouraged local governments to incorporate the concept of "Adaptation Action Area" (AAA) into their planning documents and, thus identify areas most vulnerable to coastal flooding and sea level rise in order to prioritize funding opportunities. An additional recommendation concerns the development of sea level rise scenario maps and flood maps that reflect the 100-year storm event under future sea level rise scenarios that local governments could incorporate into their Comprehensive Planning documents. Building and land use codes should be revised to reduce losses from new construction or redevelopment in areas vulnerable to sea level rise and flooding.

In July 2013, Miami-Dade County formed the Sea-Level Rise Task Force charged with making recommendations to the County's Comprehensive Development Master Plan (CDMP). The principal Task Force recommendation in July 2014 was to "accelerate the adaptation planning process by seeking and formally selecting the engineering and other relevant expertise needed" to develop plans for flood protection, salinity barriers, pumps, and road/bridge designs (Miami-Dade County, 2014b). The Task Force also recommended that the County to implement the AAA concept that had been called for in the CDMP incorporating the best available data on sea level rise and storm surges. The report also encouraged MDC to coordinate with other SEFRCCC partners and the South Florida Water Management District to develop and adopt strategies to address flooding damage and salinity intrusion resulting from sea level rise.

The current (2017) Miami-Dade County CDMP for 2020-2030 contains 12 elements, several which directly address climate change and sea level rise. The two most relevant elements are Land Use and Coastal Management. The Land Use Element states lofty goals of identifying hazard-prone areas and areas vulnerable to SLR and tidal flooding; identifying the most vulnerable public infrastructure (road and bridges, wastewater treatment plants, transmission lines, airports and seaports, fire stations); developing appropriate design standards; revising the Land Use and Zoning Maps to take flooding and storm surge risk into account; coordinating efforts with other jurisdictions, and not subsidizing programs that encourage growth on barrier islands (Miami-Dade County, 2017d). The Coastal Management Element calls for County planning, regulations, and programs to direct population concentrations away from Coastal High Hazard Areas and FEMA " $\mathrm{V}$ " Zones. This element also states that SLR projections determined by the SEFRCCC should be considered in all future County decisions regarding location, design, 
and development of public facilities and infrastructure (Miami-Dade County, 2017d). These goals are important first steps, but they remain to be fully implemented.

In November 2017 the Office of Emergency Management of Miami-Dade County released an updated Miami-Dade County, Florida Comprehensive Emergency Management Plan (CEMP) (Miami-Dade County, 2017c). This extensive document specifies the responsibilities of the federal, state, and local governments, as well as organized stakeholders, in the face of various emergency situations that may occur and attempts to coordinate planning, response, mitigation, and recovery from identifiable hazards. Among the medium and high risk hazards the CEMP identifies are hurricanes, flooding, and climate change. For example, the Emergency Operations Center has identified 5 storm surge planning zones based on current sea levels. Evacuation would be required from a larger number of zones with increasing hurricane intensity. A Category 5 hurricane with projected path striking the central most populated part of the County could require the evacuation of 2.4 million persons or essentially the entire population.

While Miami-Dade County has only recently begun to expressly consider the risks of sea level rise, the region has extensive experience in measures associated with coastal erosion and shoreline protection. The 1926 Category 3 hurricane that struck Miami caused major damage to infrastructure and significant beach erosion on Miami Beach. The first efforts to address coastal erosion began shortly afterward with construction of wood and rock groins. Eventually the structures were located on practically every block of Miami Beach. By the 1950s, no dry sand beach existed on $56 \%$ of the shoreline at high tide. In 1966 Congress authorized the Miami-Dade County Beach Erosion Control and Hurricane Surge Protection Program via the Flood Control Act with the primary goal of addressing beach erosion. Development and implementation of this major beach nourishment program was a cooperative arrangement between the US Army Corps of Engineers (USACE) and Miami-Dade County. The original project, carried out between 1975 and 1982, called for nourishment of 10.5 miles $(\sim 17 \mathrm{~km})$ of beach from Government Cut to Haulover Beach with sand dredged from offshore borrow sites. The plan called for creation of a 75 foot $(22.9 \mathrm{~m})$ wide surge protection dune and a 50 foot $(15.2 \mathrm{~m})$ flat berm at +9.0 feet $(+2.74 \mathrm{~m})$. Plans called for the restored beach to extend between 225 and 280 feet $(68.6$ and $85.3 \mathrm{~m}$ ) seaward of the Erosion Control Line. The beach design would lead to an $80 \%$ reduction in storm damage during a 100 -year storm event. The initial project excavated some $13,878,000$ cubic yards of sand $(10,616,670$ cubic meters) from offshore borrow sites at a cost of $\$ 56.8$ million.

In 1986 the U.S. Congress via the Water Resources Development Act authorized the second phase of the project that was completed in 1988. This phase extended the nourishment an additional 2.5 miles $(4.0 \mathrm{~km})$ north along Sunny Isles Beach. The project created a beach with 20 foot $(6.1 \mathrm{~m})$ wide berm at +9.0 feet $(+2.74 \mathrm{~m})$. The second project phase utilized some $1,496,000$ cubic yards $(1,144,440$ cubic meters) of sand at a cost of $\$ 19.3$ million. Smaller projects to address erosion hotspots have been carried out 
since completion of the original beach nourishment project. As of 2006, some $18,401,000$ cubic yards $(14,076,765$ cubic meters) of sand had been excavated for the initial beach nourishment project and project maintenance. The Miami Beach project is thought to be one of the most durable replenishment projects on the US Atlantic and Gulf of Mexico coasts (Pilkey and Dixon, 1996).

All levels of government contribute funding for these beach replenishment projects. The original agreement provided $50 \%$ of the cost through federal Congressional appropriations. Initially the State of Florida through the Department of Natural Resources contributed $75 \%$ of the non-federal project expenses with the remainder coming from County funds (\$9.1 million). However, the State share has decreased to a maximum of $50 \%$ of the non-federal costs.

Additionally, the State of Florida Building Commission adopts the Florida Building Code (FBC) and considers amendments every three years. In response to Hurricane Andrew (1992) that caused major damage in Miami-Dade County, the FBC incorporated stricter building standards for construction, alteration, modification, and repair of buildings in Miami-Dade and Broward County, both classified as a "high-velocity hurricane zone". These standards are based on those adopted by the American Society of Civil Engineers (ASCE 7-98) that ensure that buildings are able to withstand wind velocities of $170 \mathrm{mph}$ (274 kph) (Broward) and $175 \mathrm{mph}$ (282 kph) (Miami-Dade). Additional protection, such as impact resistant glass, is required in Miami-Dade and Broward for wind-borne debris.

The barrier island City of Miami Beach is the municipality in MDC that has been most aggressive in addressing flooding from SLR. In 2014 the municipality began to implement the Miami-Dade County recommendation to address sea level rise with the development of design standards for city infrastructure that would account for sea level rise during a 30 to 50 year time horizon. For example, basic standards were altered to increase the storm rainfall events from 6 to 7.5 inches $(15.24$ to $19.05 \mathrm{~cm})$ during a 24 hour period, and tailwater elevations were increased from 0.67 to 2.7 feet (20.4 to 82.3 $\mathrm{cm}$ ) North American Vertical Datum (NAVD). Based on these standards, design standards for road elevations, stormwater outlets, seawall elevations, and building finished floor elevations were modified.

Miami Beach has begun to elevate streets in areas that are most vulnerable to flooding. The City initiated the overhaul of its stormwater system with the installation of 70 oneway pumps in areas that are most susceptible to flooding (West Avenue and Alton Road). These pumps replace the reverse gravity pumps that recently caused street flooding during king tide events. During recent flooding events, the pumps have worked, although they have been responsible for water pollution (fecal matter) in Biscayne Bay. Installation of stormwater pumps, as well as raising roads, is progressing in other areas of mid-Miami Beach. 
In April 2016 the City of Miami Beach adopted new standards for major renovation and new construction that will provide for increased protection against storm surges and sea level rise. The minimum base flood elevation (BFE) was increased from 7.0 feet NGVD to 8.0 feet (2.13 to 2.44 meters) NGVD. Similarly, the Freeboard was increased from 0 feet above BFE to +1 foot to +3 feet $(+0.305$ to +0.914 meters $)$ above BFE. Required elevations for seawalls were also increased from 4.76 feet (1.45 meter) NGVD to 7.26 feet (2.21 meters) NGVD for public seawalls and from 4.76 NGVD (1.45 meter) to 5.56 (1.69 meter) to 7.26 feet ( 2.21 meters) NGVD for private seawalls. The ordinance also established a minimum yard elevation of 6.56 feet (2.0 meters) NGVD where none existed previously.

\section{Discussion}

What do Miami and Venice have in common? Both are high-density coastal cities that are highly vulnerable to SLR and flooding. Both sites include barrier islands and shallow lagoon/bay that have experienced great anthropogenic modification - increasing the vulnerabilities. Large numerous of tourists visit both cities often by cruise ship, and, in fact, tourism is their largest economic generator. Flooding and SLR are priority issues in Venice and Miami - although the directions the cities have chosen for adaptation differ somewhat. Adaptation strategies have involved numerous levels of government in both cases. Both metropolitan areas can draw on substantial financial resources and knowledge from respected scientific institutions. While we recognize that adaptation techniques and planning processes are very site-specific (Thead, 2016), both Miami and Venice offer lessons that may have applicability elsewhere. Both cities illustrate that adaptation to SLR presents scientific/engineering issues, as well as significant sociopolitical challenges.

\subsection{Venice}

In this historic city and UNESCO World Heritage Site water and the city become almost indistinguishable. Venice has centuries of experience in adaptation to flooding and construction on the water. In 1966, however, this experience was insufficient to protect the city from a combination of Sirocco winds and high tides. Since then acqua alta flooding has become much more serious and frequent - due to regional subsidence, as well as SLR. Adaptation responses have emanated from all levels of government. The municipality developed warning plans and designated elevated walkways for residents and tourists. Interventions have also included pumps, abandonment of the ground floors of some buildings, wetland creation and restoration, beach nourishment, and seawalls. The issue was also addressed at the highest government level (the Nation/Stato) with a series of Special Laws that provided significant funding for major infrastructure projects that were intended to safeguard the historic region. The jewel infrastructure project was MoSE - three state-of-the-art mobile gates that would close the lagoon's entry channels to the Adriatic during high tide events. However, the MoSE project, designed almost four decades ago, has failed to integrate new information 
about SLR into its evaluation of impacts. As a result, projections suggest that the gates may be closed more often than not - with great ecological and econcomic impacts for Venice and its Lagoon. Essentially, with future SLR, the MoSE will become an extremely costly and unacceptable intervention. The top-down approach of the contractor Consorzio Venezia Nuova(CVN) - and reliance on an experimental high-tech megaproject alientated many stakeholders and officials at lower levels of government. Issues of CVN corruption have led to great delays, abandonment of other adpatation measures, and an institutional vacuum in addressing the SLR threat.

So despite the great historical experience of Venice against flooding, the choice of MoSE has proved to be very problematic (Flyvbjerg, 2003). The Venice situation is currently at an impasse where little has changed, and the lack of a democratic process regarding the selection of different options has stifled more comprehensive debate about the multiple impacts of SLR on Venice and its Lagoon. In recent years the only public discussion in Venice concerns MoSE and the passage of large vessels within the lagoon and into the heart of the historic city (San Marco Basin and Giudecca Canal). With respect to MoSE, after judicial magistrates discovered evidence of corruption, all CVN interventions have been suspended except for construction of the sea gates. The final delivery date for MoSE has been delayed and is now scheduled tentatively for 2020-2022, instead of the original completion date of 2012. Additionally, construction has been flawed with use of substandard materials, and now there are numerous protests and further delays. Some individuals question the utility of MoSE, but most people believe that the project should not be abandonned because $€ 4.5$ billion has already been invested. Concerning adaptation to flooding and SLR, the only proposal presently being implemented is the MoSE. Today discussion is absent about the future of the barrier islands (Lido and Pellestrina) and the economic and environmental vulnerabilities that Venice (as well as the islands of Murano and Burano) may face by 2050 or 2100 in light of a $50-100 \mathrm{~cm}$ rise in sea level. In short, Venice has overrelied on the large experimental infrastructure alternative and has failed to incorporate adaptive management.

Problems related to the entry of large vessels into the heart of the historic city began to attract attention six years ago after the shipwreck of the Costa Concordia. Legislation prohibits cruise ships from entering the lagoon because of the risks they create when passing through the Grand Canal, and institutions were obligated to find an "alternative route". However, a temporary exception was created that still remains in force. The competent institutions have already proposed several alternatives that have been rejected for various reasons (environmental impacts, risks, need to dredge etc.). The NoNAVI Committee proposes to move the maritime station outside the lagoon to Lido (near the MoSE), but currently no environmental and economically viable proposal appears acceptable to all stakeholders.

In summary, all the SLR debates are related to MoSE. Compounding this limited focus, we note an "institutional bottleneck" and vacuum. The intervened CVN and its Commissioner are focused solely on completion of MoSE infrastructure and currently 
limit public participation and outreach. The Water Magistrate with its broad functions has been abolished, and the new Metropolitan City that should replace the City of Venice has yet to coalesce. Authorities appear unwilling to communicate with the public and express uncertainty regarding their future roles or actions. The high level of institutional fragmentation continues.

\subsection{Miami}

Urban Miami has a short history of a little over a century as a fantasy tropical "paradise" artificially built on a coastal wetland and barrier island. Poor land use planning in the past has led to serious vulnerability today that will be very expensive to address. Miami has destroyed coastal ecosystems (coastal wetlands, coral reefs) that could have helped mitigate the impacts of SLR. Its low elevation, porous limestone bedrock substrate, susceptibility to tropical storms and hurricanes, as well as SLR, create a situation of high vulnerability to flooding and storm surge. The region's population has experienced rapid growth, and today over 2.6 million people reside in Miami-Dade County. High rates of population and infrastructure growth continue despite Miami's uncertain future. However, awareness and concern about SLR is recent but growing rapidly. Initial efforts to address the threats have begun at the county and city levels with little political and financial support from the national and state levels (with the exception of beach renourishment projects). For the most part, initial activity largely involves planning goals with little actual implementation - although the relatively wealthy and progressive City of Miami Beach has begun to elevate some streets, install pumps, and approve new construction regulations. The region's porous limestone substrate and vulnerability to hurricane storm surges make the adoption of mobile sea barriers similar to those in Venice impractical.

There is a growing level of awareness of the vulnerability that the region faces as a result of SLR, in addition to storm surge caused by hurricanes. Recent experiences with devastating hurricanes (Andrew 1992 and Irma 2017), as well as king tide flooding events that have drawn much media attention, appear to have begun to create sensitivity in the region to scenarios of impacts from SLR in the coming decades (Wachinger et al., 2013; Treuer et al. 2018). This increasing awareness may help to overcome short-term vision and "wait-and-see" attitudes.

Adaptation will be expensive and push existing technologies. Recent models estimate the costs of adaptation (shoreline armoring, beach renourishment, abandoned properties, elevation of land and structures) through 2100 to SLR and additionally SLR combined with storm surge. Adaptation costs in Miami rank the highest of any US city $\$ 51$ billion to adapt to SLR and \$130 billion to adapt to SLR and storm surge (Neumann et al., 2015). Recent research by Treuer et al. (2018) indicates that Miami residents (despite their political persuasion and beliefs about climate change) may be willing pay higher taxes to fund adaptation measures. For example, in November 2017 City of Miami voters approved a general obligation bond of $\$ 400$ million, half of which will pay 
for SLR mitigation and flood prevention projects, such as pumping stations and stormwater system upgrades (Magill, 2017; Smiley, 2017).

Miami's situation creates an excellent opportunity for innovation - not only regarding adaptation strategies but also in communication and outreach strategies by government officials. Conversation is focusing on new technologies that might be implemented to allow Miami to continue to exist despite SLR. These concepts include parks as water storage areas, floating homes, and increasing dependence on water transport. Some attention is beginning to identify critical infrastructure and historical structures that must be protected, as well as less "important" and more vulnerable areas that may have to be abandoned. Perhaps Miami may be able to turn the challenges it faces into opportunites and be able to develop expertise in adaptation techniques that could be used elsewhere.

\section{Concluding remarks}

How should coastal zones be managed to best adapt to the impacts of climate change, such as SLR? How severe are the threats, and what decisions and tradeoffs must be made? How should the scientific community navigate the interface between science and policy? (Orbach and Von Storch, 2011). These are critical issues that coastal decisionmakers must address (Anilkumar et al., 2010).

Clearly psychological barriers exist to concern about SLR and adopting and financing concrete adaptation measures. Distant futures of 30 or 50 years are beyond the normal planning period for governments or developers or homeowners, but good coastal management in light of climate change requires this longer planning horizon (Tobey et al., 2010). Moreover, uncertainty exists with respect to the extent of the vulnerability and possible impacts (Spence et al., 2012, Weber, 2016; Treuer et al., 2018). Despite uncertainties about the rate of SLR, vulnerable coastal cities need to address rising seas "yesterday". Delay will only close options, lead to greater losses, and result in greater future costs. Adaptation measures and projects will be very costly, so strict oversight of expenditures, perhaps by citizens' accountability boards, is absolutely essential to avoid corruption and misappropriation of funds.

Who will pay for adaptive measures? Local taxes and bonds seem to be the route that Miami is following at this time. The central government has provided high levels of funding for the most recent measures being implemented in Venice. Ideally, financial support should emanate from all levels of government in a coordinated fashion. Treuer et al. (2018) raise a potential funding challenge; if wealthy coastal residents abandon their homes and coastal real estate values plummet, shrinking local revenues may not be capable of funding adaptive measures. Banks may cease approving mortages for homes in the area or insurers may refuse to issue policies (Flavelle, 2017). Nevertheless, coastal housing values in Miami and Venice are high and appear to be increasing. Some evidence suggests that both real estate markets have fluidity that may become greater 
with increased flooding (Roberts, 2016; Keenan et al., 2018). Of course, this situation could change in the future, particularly in light of a major hurricane of exceptional flooding event.

Coastal managers should learn a lesson from wise investors - diversification. Coastal cities should not rely on one intervention, but must adopt numerous measures that to a certain extent may be redundant. Nature-based adaptation measures, such as coastal wetland creation and enhancement, must be important components of the package (Tobey et al. 2010; Fernandino et al. 2018). Venice possesses a wealth of experience over the centuries fighting against water and, particularly after the big flood of 1966 the city should have selected the best option. Today, however, many question the overreliance on the high-tech experimental mobile barriers. While from an engineering perspective the mobile gates may be a success, with rising sea levels the adverse impacts on the lagoonal ecosystem and many stakeholders may be profound.

Venice and Miami both illustrate that the complex issue of rising seas must be addressed by a combination of scientific knowledge and socio-economic expertise particularly, when 'facts are uncertain, values in dispute, stakes are high and decisions urgent' (Funtowicz and Ravetz, 1991). In these cases, the quality (fitness for purpose or function) of the process requires the participation of an "extended peer community", including all those with a stake in the relevant problem. The decision-making process must be transparent and open to all interested and affected parties - that means

It would appear that, in the two cases presented here, adaptation to SLR has not yet led to a reformulation of the problems or a structural transformation of the governance institutions that would allow the systems to progress towards more effective outcomes. In particular, planned adaptation in both cities remains limited by the lack of ecosystembased approachs and by the lack of horizontal (sectoral) and vertical (intergovernmental) Integration.

\section{Acknowledgements}

We would like to thank Andrea Barbanti for preliminar discussion on the outline of the paper.

This study was financed by IRIDE Program 2016, "DAIS Incentivi alla ricerca individuale", funded by University Ca' Foscari of Venice.

The authors declare no conflicts of interest. 


\section{References}

Adger, W.N. 2006. Vulnerability. Global Environmental Change 16:268-281.

Ammermann, A.J., and C.E. McClennen. 2000. Saving Venice. Science 289:1301-1302.

Anilkumar P.P., Varghese K. And L.S.Ganesh, 2010. Formulating a coastal zone health metric for landuse impact management in urban coastal zones. Journal of Environmental Management, 91: 2172-2185. DOI: 10.1016/j.jenvman.2010.05.021

Antonioli, F., M. Anzidei, A. Amorosi, V. Lo Presti, G. Mastronuzzi, G. Deiana, G. De Falco, A. Fontana, G. Fontolan, S. Lisco, A. Marsico, M. Moretti, P.E. Orrù, G.M. Sannino, E. Serpelloni, and A. Vecchio. 2017. Sea-level rise and potential drowning of the Italian coastal plains: Flooding risk scenarios for 2100. Quaternary Science Reviews, 158: 29-43.DOI: 10.1016/j.quascirev.2016.12.021

AOML (Atlantic Oceanographic and Meteorological Laboratory). 2009. All U.S. Hurricanes (1851-2008). Miami: NOAA/AOML, http://www.aoml.noaa.gov/hrd/hurdat/ushurrlist18512008.txt, accessed August 2016.

Araos M., Berrang-Ford L., Ford J.D., Austin S. E. and A. Lesnikowski, 2016. Climate change adaptation planning in large cities: A systematic global assessment, Environmental Science \& Policy, 66: 375-382. DOI: 10.1016/i.envsci.2016.06.009

Ariza E., Lindeman K.C., Mozumder P. and D.O. Suman, 2014. Beach management in Florida: Assessing stakeholder perceptions on governance. Ocean \& Coastal Management, 96:82-93. DOI: 10.1016/j.ocecoaman.2014.04.033

Birkmann, J. 2006. Measuring Vulnerability to Natural Hazards: Towards Disaster Resilient Societies. . United Nations University. Available at: http://archive.unu.edu/unupress/sample-chapters/1135MeasuringVulnerabilityToNaturalHazards.pdf

Borg, R.P., M. Indirli, F. Romagnoli and C. Rochas. 2014. The ANDROID case study; Venice and its territory: vulnerability and resilience in multi-hazard scenarios. Procedia Economics and Finance, 18: 825 - 836.DOI: 10.1016/S22125671(14)01008-9

Brannigan, M. 2014. A lopsided comeback: How the housing recovery favors the rich. Miami Herald, May 4, 2014. Available at http://media.miamiherald.com/static/media/projects/2014/zipcode/stories/overv iew/

Caniato G. 2005. Between salt and fresh water, in: Fletcher, C.A., Spencer, T. (Eds.), Flooding and environmental challenges for Venice and its lagoon: state of knowledge. Cambridge University Press, London UK. pp. 7-14.

Carraro, C., and A. Sgobbi. 2008. Climate Change Impacts and Adaptation Strategies In Italy. An Economic Assessment. FEEM Nota di Lavoro 6.2008, 28 pp.

Corcoran, W.T., and E. Johnson. 2005. Climate of North America. In: J.E. Oliver (ed.), Encyclopedia of World Climatology. Dordrecht, The Netherlands: Springer, pp. 525-534.

Cutter, S.L. and C. Finch. 2008. Temporal and spatial changes in social vulnerability to natural hazards. Proc Natl Acad Sci., 105: 2301-2306. DOI:

10.1073/pnas.0710375105 
Davenport, C. 2018. How Much Has 'Climate Change' Been Scrubbed From Federal Websites? A Lot. New York Times, January 10, 2018. Available at: New York Times,. https://www.nytimes.com/2018/01/10/climate/climate-changetrump.html

De Sherbinin, A., A. Schiller, and A. Pulsipher. 2007. The vulnerability of global cities to climate hazards. Environment \& Urbanization, 19(1): 39-64. DOI: $10.1177 / 0956247807076725$

DeConto, R.M., and D. Pollard. 2016. Contribution of Antarctica to past and future sealevel rise, Nature,. 531:591-597. DOI: 10.1038/nature17145

Duever, M.J., J.F. Meeder, L.C. Meeder, and J.M. McCollom. 1994. The climate of south Florida and its role in shaping the Everglades ecosystem. In: Davis, S.M., and J.C. Ogden (eds.), Everglades: The Ecosystem and its Restoration. Delray Beach, Florida: St. Lucie Press, pp. 225-248.

European Environment Agency. 2015. Adaptation of integrated coastal management plans. http://climate-adapt.eea.europa.eu/metadata/adaptation-

Fagherazzi, S., L. Carniello, L. D’Alpaos, and A. Defina. 2006. Critical bifurcation of shallow microtidal landforms in tidal flats and salt marshes. In: Proc. of the National Academy of Sciences of the United States of America, PNAS 103(8337): 8337-8341. DOI: doi.org/10.1073/pnas.0508379103

Favero, G. 2014. Venezia dopo Venezia: economia e demografia urbana nel novecento (in italian). Laboratoire Italien, 15:79-89.

Fernandino G., Elliff C.I. and I.R. Silva, 2018. Ecosystem-based management of coastal zones in face of climate change impacts: Challenges and inequalities. Journal of Environmental Management, 215:32-39. DOI: 10.1016/j.jenvman.2018.03.034

Flavelle, C. 2017. The nightmare scenario for Florida's coastal homeowners. Bloomberg News, April 19, 2017. Available at: https://www.bloomberg.com/news/features/2017-04-19/the-nightmare-scenariofor-florida-s-coastal-homeowners

Flyvbjerg, B. 2003. Megaprojects and Risks: An Anatomy of Ambition. Cambridge University Press. DOI: 10.1108/09513550410530199

FAO. 2015. Mediterranean coastal lagoons: sustainable management and interactions among aquaculture, capture fisheries and the environment. Studies and Reviews. General Fisheries Commission for the Mediterranean. No 95. Rome, FAO, 278 pp. www.fao.org/3/a-i4668e.pdf

Fu, X., M. Gomaa, Y. Deng, and P. Zhong-Ren. 2017. Adaptation planning for sea level rise: A study of US coastal cities. Journal of Environmental Planning and Management 60(2):249-265. DOI: 10.1080/09640568.2016.1151771

Funtowicz, S. O., and J.R. Ravetz. 1991. A New Scientific Methodology for Global Environmental Issues, in Costanza, R. (ed.), Ecological Economics: The Science and Management of Sustainability, pp. 137-152. New York: Columbia University Press.

Gamio, L. 2016. 100 years of hurricanes hitting and missing Florida, visualized. Washington Post, 7 October 2016. At https://www.washingtonpost.com/graphics/national/one-hundred-years-ofhurricanes/ 
Ghezzo M., Guerzoni, S., Cucco, A., Umgiesser, G.. 2010. Changes in Venice Lagoon dynamics due to construction of mobile barriers, Coastal Engineering, 57: 694708. DOI: 10.1016/i.coastaleng.2010.02.009

Ghose, T. 2013. "The 20 Cities Most Vulnerable to Flooding," Live Science, August 18, 2013.

Goodell, J. 2017. The Water Will Come: Rising Seas, Sinking Cities, and the Remaking of the Civilized World. Little, Brown, and Company: New York.

Grunwald, M. 2007. The Swamp: The Everglades, Florida, and the Politics of Paradise. New York: Simon and Schuster.

Hallengatte, S., C. Green, R.J. Nicholls, and J. Corfee-Morlot. 2013. Future flood losses in major coastal cities. Nat. Clim. Change 3:802-806. DOI: 10.1038/nclimate1979

Hanson, S., R. Nichols, N. Ranger, S. Hallegarte, J. Corfee-Morlot, C. Herweijer, C. Chateau. 2011. A global ranking of port cities with high exposure to climate extremes. Climate Change 104:89-111

Hauer, M.E., J.M. Evans, and D.R. Mishra. 2016. Millions projected to be at risk from sealevel rise in the continental United States. Nature Climate Change, 6:691-695.

Hoffmeister, J.E., 1982. Land from the Sea: the Geologic Story of South Florida. University of Miami Press: Coral Gables, Florida

Idealista. 2015. Indice annuale 2015 dei prezzi delle abitazioni di seconda mano. Available at: https://st3.idealista.it/news/archivie/201512/indice_annuale_prezzi_2015.pdf.

Indirli, M., S. Knezic, R.P. Borg, Y. Kaluarachchi, B. Ranguelov, F. Romagnoli, and C. Rochas. 2014. The ANDROID case study; Venice and its territory: a general overview. Procedia Economics and Finance, 18:837-848. DOI: 10.1016/S22125671(14)01009-0

IPCC, 2014. Climate Change 2014: Synthesis Report. Contribution of Working Groups I, II and III to the Fifth Assessment Report of the Intergovernmental Panel on Climate Change [Core Writing Team, R.K. Pachauri and L.A. Meyer (eds.)]. IPCC, Geneva, Switzerland, $151 \mathrm{pp}$.

Kaluarachchi Y., Indirli M., Ranguelov B. and F. Romagnoli. 2014. The ANDROID case study; Venice and its territory: existing mitigation options and challenges for the future. Procedia Economics and Finance, 18: 815-824.DOI: 10.1016/S22125671(14)01007-7

Keahey J., 2002. Venice Against the Sea : A City Besieged. St. Martin's Press.

Keenan, J.M., T. Hill, and A. Gumber. 2018. Climate gentrification: From theory to empiricism in Miami-Dade County, Florida. Environ. Res. Lett. 13:054001.

Kemp, A. C., and B. P. Horton. 2013. Contribution of relative sea-level rise to historical hurricane flooding in New York City, J. Quat. Sci., 28: 537-541.DOI: 10.1002/jqs.2653

Kirwan M.L. and J.P. Megonigal, 2013. Tidal wetland stability in the face of human impacts and sea-level rise. Nature, 504: 53-60. DOI: 10.1038/nature12856

Klein, R.J.T., R.J. Nicholls, and F. Thomalla. 2003. Resilience to natural hazards: how useful is this concept? Global Environmental Change Part B: Environmental Hazards, 5:35-45.DOI: 10.1016/j.hazards.2004.02.001 
Kopp, R.E., A.C. Kemp, K. Bittermann, B.P. Horton, J.P. Donnelly, W.R. Gehrels, C.C. Hay, J.X. Mitrovica, E.D. Morrow, and S. Rahmstorf. 2016. "Temperature-driven global sea-level variability in the Common Era," in Proceedings of the National Academy of Sciences 113 (2016): E1434-E1441. Retrieved from http://www.pnas.org/content/113/11/E1434.

Korten, T. 2015. "Gov. Rick Scott's ban on climate change term extended to other state agencies," Miami Herald, March 11, 2015.

Kulp S., and B.H. Strauss. 2017. Rapid escalation of coastal flood exposure in US municipalities from sea level rise. Climate Change 142:477-489.

Juhola S. and L.Westerhoff, 2011. Challenges of adaptation to climate change across multiple scales: a case study of network governance in two European countries. Environmental Science \& Policy, 14: 239-247.

Lambeck, K., F. Antonioli, M. Anzidei, L. Ferranti, G. Leoni, G. Scicchitano, and S. Silenzi. 2011. Sea level change along the Italian coast during the Holocene and projections for the future. Quaternary International 232: 250-257.

Lodge, T.E. 2010. The Everglades Handbook: Understanding the Ecosystem. CRC Press: Boca Raton, Florida.

Magill, B. 2017. Miami taxpayters asked to foot the bill to protect the city from climate change. Climate Liability, August 16, 2017. Available at: https://www.climateliabilitynews.org/2017/08/16/miami-florida-climate-changesea-level-rise-adaptation/

Mancuso, F. 2014. Building on Water: The surprising expedients that made possible the birth and growth of Venice. Corte del Fontego Editore: Venice.

Marsico A. et al., 2017. Flooding scenario for four Italian coastal plains using three relative sea level rise models, Journal of Maps, 13:2, 961-967, https://doi.org/10.1080/17445647.2017.1415989

MAV-CVN. 2013. Gestione sostenibile dell'identità lagunare veneziana, C. 1 . 14, Doc. 70786-REL-T003. 0., 230 pp.

Melick, A. 2010. A Century of Service: A History of the Biscayne Bay Pilots. Biscayne Bay Pilots Association: Miami.

Miami-Dade County. 2009. Recent population Miami-Dade County Florida, by Municipality, 1900-2007. At http://www.miamidade.gov/planning/library/reports/2009-miami-dade-countyfacts.pdf

Miami-Dade County. 2014a. Climate Change Action Plan. Available at: https://www.miamidade.gov/greenprint/pdf/climate_action_plan.pdf

Miami-Dade County. 2014b. Sea Level Rise Task Force Report and Recommendations. July 1, 2014. Available at:

http://www.miamidade.gov/planning/library/reports/sea-level-rise-reportrecommendations.pdf.

Miami-Dade County. 2017a. The cruise capital of the world hosts 5.3 million passengers in 2017. Available at http://www.miamidade.gov/portmiami/press releases/201711-13-cruise-capital-record.asp 
Miami-Dade County. 2017b. The local and regional economic impacts of PortMiami. March 28, 2017.

Miami-Dade County. Department of Regulatory and Economic Resources. 2017d. Adopted Components: Comprehensive Development Master Plan for Miami-Dade County, Florida. Available at: https://www.miamidade.gov/planning/cdmpadopted.asp

Miami-Dade County. Office of Emergency Management. 2017c. Miami-Dade County, Florida Comprehensive Emergency Management Plan (CEMP). Available at: http://www.miamidade.gov/fire/library/OEM/CEMP.pdf

Molinaroli, E., S. Guerzoni, A. Sarretta, M. Masiol, and M. Pistolato. 2009. Thirty-year changes (1970-2000) in bathymetry and sediment texture recorded in the lagoon of Venice sub-basins, Italy. Marine Geology 258, 115-125.

Munaretto, S., and D. Huitema. 2012. Adaptive comanagement in the Venice lagoon? An analysis of current water and environmental management practices and prospects for change. Ecology and Society 17(2): 19. Available at: http://dx.doi.org/10.5751/ES-04772-170219

National Academy of Sciences. 2012.Disaster Resilience: A National Imperative, The National Academies Press,Washington, D.C. 260pp. DOI 10.17226/13457

Natural Resources Defense Council. 2012. NRDC, "Ready or not: An evaluation of state climate and water preparedness planning," NRDC Issue Brief 12-03-A, April 2012.

Neumann, J.E., K. Emanuel, S. Ravela, L. Ludwig, P. Kirshen, K. Bosma, and J. Martinich. 2015. Joint effects of storm surge and sea-level rise on US Coasts: New economic estimates of impacts, adaptation, and benefits of mitigation policy. Climate Change 129:337-349.

Nicholls, R.J. 2011. Planning for the impacts of sea level rise. Oceanography 24(2):144157. DOI: doi.org/10.5670/oceanog.2011.34

Obeysekera, J., J. Browder, L. Hornung, and M.A. Harwell. 1999. The natural South Florida system I: Climate, geology, and hydrology. Urban Ecosystems 3:223-244.

Orbach, M.K., and H. Von Storch. 2011. Climate Change, the Science Policy Interface and Coastal Zone Management. https://www.ecologic.eu/4156.

Panza G.F., Bisignano D. and F. Romanelli, 2014. Does MoSE cope with inland tsunamis hazard? arXiv:1406.2821 [physics.geo-ph] https://arxiv.org/ftp/arxiv/papers/1406/1406.2821.pdf

Passeri, D. L., S. C. Hagen, S. C. Medeiros, M. V. Bilskie, K. Alizad, and D. Wang, 2015. The dynamic effects of sea level rise on low-gradient coastal landscapes: A review, Earth's Future, 3, 159-181, doi:10.1002/2015EF000298.

Pfeffer, W.T., J.T. Harper, and S. O'Neel. 2008. Kinematic constraints on glacier contribution to $21^{\text {st }}$-century sea-level rise. Science 321(5894):1340 -1343. DOI: $10.1126 /$ science.1159099.

Pilkey, O.H., and K.L. Dixon. 1996. The Corps and the Shore. Island Press: Washington, D.C.

Rahmstorf, S. 2007. A semi-empirical approach to projecting future sea level rise. Science, 315, 368-370. 
Ramieri, E, Hartley A, Barbanti A, Duarte Santos F, Gomes A, Hilden M, Laihonen P, Marinova N. And M. Santini. 2011. Methods for assessing coastal vulnerability to climate change, European Topic Centre on Climate Change Impacts, Vulnerability and Adaptation (ETC CCA) Technical Paper, Bologna (IT), p 93.

Rao, K. 2016. Climate change and housing: Will a rising tide sink all homes? Zillow document. Zillow Research, June 2, 2017. Available at:

https://www.zillow.com/research/climate-change-underwater-homes-12890/

Rizzi J., Torresan S., Zabeo A., Critto A., Tosoni A., Tomasin A. and A. Marcomini. 2017. Assessing storm surge risk under future sea-level rise scenarios: a case study in the North Adriatic coast. Journal of Coastal Conservation, 21:453-471.

Roberts, H. 2016. Venice: Is the sinking sity a rising market for homebuyers? Financial Times, March 3, 2016. Available at: https://www.ft.com/content/358c67d8-dbb311e5-a72f-1e7744c66818.

Rusconi, A. 2016. La gestione della laguna con la soppressione del Magistrato alle Acque. In: Salvaguardia domani, oltre il MOSE. Sala S.Leonardo 4/11/2016 (in italian).

Sarretta A., S. Pillon, E. Molinaroli, S. Guerzoni, and G. Fontolan. 2010. Sediment budget in the Lagoon of Venice, Italy. Continental Shelf Research 30, 934-949. DOI: 10.1016/i.csr.2009.07.002

Seccombe, W. 2013. "Florida Tourism By the Numbers," Sunshine Matters: The Official Corporate Blog for VisitFlorida, March 13, 2013, Available at http://www.visitfloridablog.org/?p=6284.

Smiley, D. 2017. Miami gets $\$ 200$ million to spend on sea rise as voters pass Miami Forever bond. Miami Herald, November 8, 2017. Available at:

http://www.miamiherald.com/news/politicsgovernment/election/article183336291.html

Southeast Florida Regional Climate Change Compact Counties. 2012 .A Region Responds to a Changing Climate: Regional Climate Action Plan.

Spence, A., W. Poortinga, N. Pidgeon. 2012. The psychological distance of climate change. Risk Analysis 32:957-972.

Stewart- Muniz, S. 2016. Miami-Dade's total property value jumps to $\$ 250$ billion in 2016. The Real Deal, June 1, 2016. Available at https://therealdeal.com/miami/2016/06/01/miami-dades-total-property-valuejumps-to-250-billion-in-2016/.

Suburban Stats. 2018. At https://suburbanstats.org/population/florida/list-of-countiesand-cities-in-florida\#CK

Suman D., S. Guerzoni, and E. Molinaroli. 2005. Integrated coastal management in the Venice lagoon and its watershed. Hydrobiologia, 550:251-269.

Sweet, W., R. Kopp, C. Weaver, J. Obeysekera, R. Horton, E.R. Thieler, and C. Zervas. 2017. Global and Regional Sea Level Rise Scenarios for the United States. Silver Spring, Maryland.

Teatini P., L. Tosi, T. Strozzi, L. Carbognin, G. Cecconi, R. Rosselli, and S. Libardo. 2012. Resolving land subsidence within the Venice Lagoon by persistent scatterer SAR interferometry. Physics and Chemistry of the Earth 40-41, 72-79. 
Thead, E.A. 2016. Sea level rise: Risk and resilience in coastal cities. The Climate Institute http://climate.org/wp-content/uploads/2016/10/Erin-Sea-levels.pdf

Tobey, J., P. Rubinoff, D. Robadue, G. Ricci, R. Volk, J. Furlow, and G. Anderson. 2010. Practicing coastal adaptation to climate change: Lessons from integrated coastal management. Coastal Management 38:317-335.

Torresan, S., A. Critto, J. Rizzi, and A. Marcomini. 2012. Assessment of coastal vulnerability to climate change hazards at the regional scale: the case study of the North Adriatic Sea. Nat Hazards Earth Syst Sci 12(7):2347-2368.

Tosi L., Teatini P., Strozzi T. and , C. Da Lio. 2014. Relative land subsidence of the Venice coastland, Italy. Engineering Geology for Society and Territory, 4:171-173.

Treuer, G., K. Broad, and R. Meter. 2018. Using simulations to forecast homeowner response to sea level rise in South Florida: Will they stay or will they go? Global Climate Change 48:108-118.

Trincardi, F., A. Barbanti, M. Bastianini, A. Benetazzo, L. Cavaleri, J. Chiggiato, A. Papa, A. Pomaro, M. Sclavo, L. Tosi, and G. Umgiesser. 2016. The 1966 flooding of Venice: What time taught us for the future. Oceanography 29(4):178-186, https://doi.org/10.5670/oceanog.2016.87.

Turner, B.L., Kasperson, R.E., Matson, P.A., McCarthy, J.J., Corell, R.W., Christensen, L., Eckley, N., Kasperson, J.X., Luers, A., Martello, M.L., Polsky, C., Pulsipher, A., and Schiller A. 2003. A framework for vulnerability analysis in sustainability science. Proceedings of the National Academy of Sciences, 100: 8074-8079.

Umgiesser, G. and B. Matticchio. 2006. Simulating the mobile barrier (MOSE) operation in the Venice Lagoon, Italy: global sea level rise and its implication for navigation. Ocean Dynamics 56: 320-332. DOI 10.1007/s10236-006-0071-4

Union of Concerned Scientists. 2017. Encroaching Tides in Miami-Dade County, Florida, UCS Fact Sheet, pp. 1-10.

https://www.ucsusa.org/sites/default/files/attach/2016/04/miami-dade-sealevel-rise-tidal-flooding-fact-sheet.pdf

UNESCO. 2011. From Global to Regional: Local Sea Level Rise Scenarios Focus on the Mediterranean Sea and the Adriatic Sea. Workshop "The future of Venice and its lagoon", Report 1, 15 pp. (http://www.unesco.org/venice/thefutureofvenice)

UNISDR. 2009. Terminology on Disaster Risk Reduction, United Nations International Strategy for Disaster Reduction, Geneva, 35 pp. Available via: https://www.unisdr.org/files/7817_UNISDRTerminologyEnglish.pdf

Valle-Levinson, A., A. Dutton, and J. B. Martin. 2017. Spatial and temporal variability of sea level rise hot spots over the eastern United States, Geophys. Res. Lett., 44:7876-7882. doi:10.1002/2017GL073926

Varrani, A., and M. Nones. 2017. Vulnerability, impacts and assessment of climate change on Jakarta and Venice. International Journal of River Basin Management, DOI: 10.1080/15715124.2017.1387125.

Veneto Regional Government and the University of Padova, 2016. Gestione integrate della fascia costiera: studio e monitoraggio per la definizione degli interventi di difesa dei litorali dall'erosione nella regione Veneto, linee guida (Integrated management of the coastal zone: Study and monitoring for the definition of the 
interventions to protect the coasts from erosion in the Veneto region, guidelines). Regione del Veneto, Giunta Regionale, Dipartimento del Suolo e Foreste, Sezione Difesa del Suolo, Eds. Paolo Ruol and Tiziano Pinato, 335 pp.

Vergano L., and P. Nunes. 2007. Analysis and evaluation of ecosystem resilience: an economic perspective with an application to the Venice lagoon. Biodivers. Conserv. (2007) 16:3385-3408. DOI 10.1007/s10531-006-9085-y.

Vergano L., G. Umgiesser and P. Nunes, 2010. An economic assessment of the impact of the MOSE barriers on Venice port activity. FEEM Sustainable Development Series, Report 17/2010, 35 pp.

Vermeer, M., and S. Rahmstorf. 2009. Global sea level linked to global temperature. Proc. Natl. Aca. Sci. 106:51.

Wachinger, G. O. Renn, C. Begg, and C. Kuhlicke. 2013. The risk perception paradoxImplications for governance and communication of natural hazards. Risk Analysis 33:1049-1065.

Wdowinski, S., R. Bray, B.P. Kirtman, and Z. Wu. 2016. Increasing flooding hazard in coastal communities due to rising sea level: Case study of Miami Beach, Florida. Ocean \& Coastal Management 126:1-8.

Weber, E.U. 2016. What shapes perceptions of climate change? New research since 2010. Wiley Interdisciplinary Rev. Climate Change 7:125-134. Available at: https://doi.org/10.1002/wcc.377

Wisner, B., Blaikie, P., Cannon, T., \& Davis, I. 2004. At Risk: Natural hazards, people's vulnerability and disasters (2nd ed.). New York: Routledge.

Zanuttigh B. 2011. Coastal flood protection: What perspective in a changing climate? The THESEUS Approach, Environmental Science and Policy, 14:845-863. DOI 10.1016/i.envsci.2011.03.015 


\section{SUPPLEMENTARY MATERIAL (Molinaroli et al.)}

Table 1. Chronology of events recognized as strong factors able to affect structures and processes in the morpho-bathymetry of LV from1880 to present time (modified from Sarretta et al., 2010*).

\begin{tabular}{|c|c|c|}
\hline & Event & Notes \\
\hline \multicolumn{3}{|l|}{ First period } \\
\hline $1880-1900$ & $\begin{array}{l}\text { First instrument monitoring } \\
\text { water level }\end{array}$ & Tidal gauge at Punta della Salute \\
\hline $1882-1910$ & New jetties at Lido inlet & $\begin{array}{l}\text { Modification of lagoon-sea } \\
\text { exchanges }\end{array}$ \\
\hline 1910-1934 & New jetties at Chioggia inlet & $\begin{array}{l}\text { Modification of lagoon-sea } \\
\text { exchanges }\end{array}$ \\
\hline 1928 & $\begin{array}{l}\text { Fish farming areas separated } \\
\text { from rest of } L V\end{array}$ & $\begin{array}{l}\text { Reduction of lagoon surface } \\
\text { area }\left(85 \mathrm{~km}^{2}\right) / \text { reduction of } \\
\text { water residence time }\end{array}$ \\
\hline 1917-1935 & $\begin{array}{l}\text { Land reclamation for } 1^{\text {st }} \\
\text { industrial zone (IZ) }\end{array}$ & $\begin{array}{l}\text { Saltmarsh destruction, (5 } \\
\mathrm{km}^{2} \text {,west of city of Venice) }\end{array}$ \\
\hline 1931-1934 & $\begin{array}{l}\text { Construction of trans-lagoon } \\
\text { bridge (Ponte della Libertà) }\end{array}$ & $\begin{array}{l}\text { Modification of tidal current } \\
\text { pattern }\end{array}$ \\
\hline 1950-1953 & $\begin{array}{l}\text { Land reclamation for } 2^{\text {nd }} \\
\text { industrial zone }\end{array}$ & $\begin{array}{l}\text { Saltmarsh destruction }\left(5 \mathrm{~km}^{2},\right. \\
\text { south of } 1 \mathrm{st} \mathrm{IZ})\end{array}$ \\
\hline 1957 & $\begin{array}{l}\text { Land reclamation for housing } \\
\text { (S. Giuliano, east of Mestre) }\end{array}$ & $\begin{array}{l}\text { Saltmarsh destruction }\left(2 \mathrm{~km}^{2}\right. \\
\text { north of trans-lagoon bridge) }\end{array}$ \\
\hline 1958-1962 & Airport construction & $\begin{array}{l}\text { Saltmarsh destruction }\left(\sim 3 \mathrm{~km}^{2}\right) \text {, } \\
\text { excavation of new artificial } \\
\text { canal from airport to Venice }\end{array}$ \\
\hline 1962 & $\begin{array}{l}\text { Land reclamation for } 3^{\text {rd }} \\
\text { industrial zone (never } \\
\text { completed), now called "Casse } \\
\text { di Colmata", i.e., unfinished } \\
\text { reclamation islands }\end{array}$ & $\begin{array}{l}\text { Saltmarsh destruction }\left(12 \mathrm{~km}^{2} \text {, }\right. \\
\text { south of } 2 \mathrm{nd} \mathrm{IZ)}\end{array}$ \\
\hline 1966-1969 & $\begin{array}{l}\text { Excavation of Malamocco- } \\
\text { Marghera navigation channel } \\
\text { ("Oil Canal") }\end{array}$ & $\begin{array}{l}30-50 \mathrm{Mm} 3 \text { of sediments } \\
\text { disposed of in landfill areas } \\
\text { outside the lagoon/modification } \\
\text { of hydrodynamic conditions }\end{array}$ \\
\hline 1930-1970 & $\begin{array}{l}\text { Major development of } \\
\text { industrial activities }\end{array}$ & $\begin{array}{l}\text { From } 1932 \text { to } 1972, \sim 12 \mathrm{~cm} \text { of } \\
\text { subsidence were due to water } \\
\text { extraction for industrial use }\end{array}$ \\
\hline \multicolumn{3}{|l|}{ Second period } \\
\hline From '70s on & $\begin{array}{l}\text { Dredging of Porto Marghera } \\
\text { channels }\end{array}$ & $\begin{array}{l}\text { Disposal of } 5-15 \mathrm{Mm}^{3} \text { of } \\
\text { polluted sediments, in part } \\
\text { outside lagoon }\end{array}$ \\
\hline $\begin{array}{l}\text { 1970-1980 } \\
\text { inside lagoon }\end{array}$ & $\begin{array}{l}\text { Increased discharges from } \\
\text { industrial area (nutrients, } \\
\text { metals, POPs) }\end{array}$ & $\begin{array}{l}\text { Part of sediments becoming } \\
\text { more and more polluted, and } \\
\text { thus not suitable for re-use }\end{array}$ \\
\hline $\begin{array}{l}80 \mathrm{~s} \\
\text { (Continued) }\end{array}$ & $\begin{array}{l}\text { Eutrophication and subsequent } \\
\text { macro-algae blooms and anoxia }\end{array}$ & $\begin{array}{l}\text { Lagoon bed covered by high } \\
\text { quantity of biomass (up to 10- } \\
25 \mathrm{~kg} \mathrm{~m}^{-2} \text { ) }\end{array}$ \\
\hline
\end{tabular}




\begin{tabular}{|c|c|c|}
\hline Middle '80s & $\begin{array}{l}\text { Introduction of Manila clam for } \\
\text { aquaculture purposes }\end{array}$ & $\begin{array}{l}\text { Concession of lagoon areas ( } 14 \\
\left.\mathrm{~km}^{2}\right) \text { for clam cultivation and } \\
\text { harvesting (seagrass loss, } \\
\text { sediment re-suspension and } \\
\text { alteration of physical } \\
\text { properties) }\end{array}$ \\
\hline From 1990 & $\begin{array}{l}\text { Dredging for renovation of port } \\
\text { area }\end{array}$ & $\begin{array}{l}\text { 3-5 } \mathrm{Mm}^{3} \text { of sediments, partly } \\
\text { disposed of outside lagoon }\end{array}$ \\
\hline 1992 & $\begin{array}{l}\text { Construction of artificial } \\
\text { "Tresse" island to dispose of } \\
\text { polluted industrial waste }\end{array}$ & Saltmarsh destruction $\left(\sim 2 \mathrm{~km}^{2}\right)$ \\
\hline $90 \mathrm{~s}$ & $\begin{array}{l}\text { "Invasion" of LV by Manila } \\
\text { clam }\end{array}$ & $\begin{array}{l}\text { Disturbance of sediments } \\
\text { through mechanical clam } \\
\text { harvesting }\end{array}$ \\
\hline 1990-2000 & $\begin{array}{l}\text { Construction of artificial } \\
\text { saltmarshes }\left(\sim 4 \mathrm{~km}^{2}\right)\end{array}$ & $\begin{array}{l}\text { Re-use of nonpolluted } \\
\text { sediments dredged from } \\
\text { channels }\left(3-4 \mathrm{Mm}^{3}\right)\end{array}$ \\
\hline 2004-present & $\begin{array}{l}\text { Beginning of MoSE project. } \\
\text { Construction of storm surge } \\
\text { barriers. }\end{array}$ & $\begin{array}{l}\text { Modification of lagoon-sea } \\
\text { exchange and sorroundings } \\
\text { (protected areas) }\end{array}$ \\
\hline
\end{tabular}

(*) Sarretta A., Pillon S., Molinaroli E., Guerzoni S., Fontolan G. (2010). Sediment budget in the Lagoon of Venice, Italy. Continental Shelf Research 30, 934-949. DOI:

10.1016/i.csr.2009.07.002 
Table 2. Chronology of events referring to the transformation of the Biscayne Bay ecosystem able to affect structures and morphological processes (data from Cantillo et al., 2000\#).

\begin{tabular}{|c|c|c|}
\hline $\begin{array}{l}\text { CANALS, CUTS } \\
\text { AND THE MIAMI } \\
\text { RIVER }\end{array}$ & Event & Notes \\
\hline 1896 & Channel dug from Cape Florida to the Miami River & (Harlem, 1979) \\
\hline $1902-1908$ & $\begin{array}{l}\text { Government Cut Construction, widened and deepened } \\
\text { (channel providing access to the Port of Miami from the } \\
\text { ocean). }\end{array}$ & (Michel, 1976) \\
\hline 1910-1925 & $\begin{array}{l}\text { 4.25 mi of Miami Canal completed (Miami Canal was } 10 \\
\text { mi long) } \\
\text { Other canals included Snapper Creek Canal, Cutler Canal, } \\
\text { and the Coral Gables Waterway. Collins Canal through } \\
\text { part of Miami Beach. } \\
\text { Bakers Haulover completed. Haulover Cut was opened }\end{array}$ & $\begin{array}{l}\text { (Harlem, 1979); } \\
\text { (Gaby, 1990) }\end{array}$ \\
\hline 1925 & Intracoastal Waterway & $\begin{array}{l}\text { (Toner, 1979); (Michel, } \\
\text { 1976) }\end{array}$ \\
\hline 1930s & $\begin{array}{l}\text { River subjected to contamination from commercial } \\
\text { activities and sewage }\end{array}$ & (Michel, 1976) \\
\hline 1940s & Salt intrusion arrested but problems remain & \\
\hline \multicolumn{3}{|l|}{$\begin{array}{l}\text { BULKHEADING } \\
\text { AND RELATED } \\
\text { ACTIVITIES }\end{array}$} \\
\hline $1913-1925$ & $\begin{array}{l}\text { Mangroves cut down in southern Miami Beach and in } \\
\text { Miami Beach and swamps filled } \\
\text { Bayview section of Miami Shores filled. } \\
\text { Area east of Biscayne Blvd. filled to create Bayfront Park }\end{array}$ & \\
\hline 1950s & $\begin{array}{l}\text { Southern one-fourth of Key Biscayne bulk-headed and } \\
\text { filled }\end{array}$ & (Toner, 1979) \\
\hline $1970 s$ & Dredge and fill activities at Fair Isle & \\
\hline ISLANDS & & (Voss, 1974) \\
\hline 1902-1944 & $\begin{array}{l}\text { Lummus and Dodge islands; Creation of Fisher Island, } \\
\text { Belle Isle } \\
\text { Miami river dredged and material dumped on current site } \\
\text { of Claughton Island } \\
\text { Creation of: Star Island, Hibiscus Island,Palm Island, Belle } \\
\text { Isle, Rivo-Alto, Di Lido Islands and Star Island } \\
\text { Creation of: Hibiscus, San Marino and San Marco, Fair Isle, } \\
\text { Pelican Island, Islands of North Bay Village } \\
\text { Bay Harbor Islands. } \\
\text { Pelican Island bought by the City of Miami Beach }\end{array}$ & $\begin{array}{l}\text { (Chapman, 1993); } \\
\text { (Toner, 1979); } \\
\text { (Kleinberg, 1997) } \\
\text { (Gaby, 1990) } \\
\text { (US Army Corps of } \\
\text { Engineers, 1922) } \\
\text { (Voss, 1974); } \\
\text { (Kleinberg,1989); }\end{array}$ \\
\hline \multicolumn{3}{|l|}{ PORT OF MIAMI } \\
\hline 1896 & Port of Miami opens & \\
\hline 1920s & Port is primary hub for all shipping to South Florida & $\begin{array}{l}\text { (Miami-Dade County, } \\
\text { 2000) }\end{array}$ \\
\hline 1930s & Passenger service to Havana & $\begin{array}{l}\text { (Miami-Dade County, } \\
\text { 2000) }\end{array}$ \\
\hline 1964 & Dodge Island Seaport opens & $\begin{array}{l}\text { (Miami-Dade County, } \\
\text { 2000) }\end{array}$ \\
\hline
\end{tabular}




\begin{tabular}{|l|l|l|}
\hline 1976 & $\begin{array}{l}\text { First port in history to record more than one million } \\
\text { passengers in a year }\end{array}$ & (Chapman, 1993) \\
\hline 1981 & Port expanded to Lummus Island & $\begin{array}{l}\text { (Miami-Dade County, } \\
\text { 2000) }\end{array}$ \\
\hline 1991 & A record 3.9 million tons of cargo are handled in one year & $\begin{array}{l}\text { (Miami-Dade County, } \\
\text { 2000) }\end{array}$ \\
\hline 1999 & $\begin{array}{l}\text { Royal Caribbean's Voyager of the Seas, the largest cruise } \\
\text { ship ever constructed, is based at the Port }\end{array}$ & $\begin{array}{l}\text { (Miami-Dade County, } \\
\text { 2000) }\end{array}$ \\
\hline ARTIFICIAL REEFS & $\begin{array}{l}\text { (Miami-Dade County, } \\
\text { 2000) }\end{array}$ \\
\hline $1979-1991$ & $\begin{array}{l}\text { Pelican Harbor Reef (artificial reef); North Bayshore Park } \\
\text { Reef (artificial reef); Julia Tuttle Artificial Reef (artificial } \\
\text { reef); Mercy Hospital Reef (artificial reef); Rickenbacker } \\
\text { Causeway Reef (artificial reef); Brickell Area Reef (artificial } \\
\text { reef); San Souci Reef (artificial reef). }\end{array}$ & \begin{tabular}{l} 
(Pybas, 1997) \\
\hline
\end{tabular} \\
\hline
\end{tabular}

(\#) Cantillo, A. Y., Hale, K., Collins, E., Pikula L. and Caballero R. (2000). Environmental History and Annotated Bibliography. NOAA Technical Memorandum NOS NCCOS CCMA 145. 


\section{Listo of interview and related documents}

Metropolitan City (previously Venice Province): Massimo Gattolin, Resilient Venice Venice http://politicheambientali.cittametropolitana.ve.it/documenti/patto-dei-sindaci/venezia-cittametropolitana-resiliente:

Veneto Region: Roberto Pelloni. Piano Paesaggistico Regionale d'Ambito "Arco Costiero Adriatico Laguna di Venezia e Delta del Po" (Regional Landscape Plan "Adriatic Coastal Arch" Venice Lagoon and Po Delta). http://bur.regione.veneto.it/BurvServices/pubblica/DettaglioDgr.aspx?id=298620

Pellestrina Municipality: Denis Carella, , Plan of the beaches of Isola del Lido and Pellestrina

Osserva torio Laguna: Marco Favaro,: PAES del Comune di Venezia (Sustainable Energy Action Plano f Venice Municipality: http://www.comune.venezia.it/archivio/54950).

Corila: Pierpaolo Campostrini. Piano Morfologico e ambientale della Laguna di Venezia. (Morphological and Environmental Plan $\mathrm{f}$ the lagoon of Venice): http://www.va.minambiente.it/it-IT/Oggetti/Documentazione/1446/2023?pagina=1

Associazione Ambiente Venezia: Armando Danella, https://ytali.com/2018/05/03/mose-ceancora-unalternativa/

Antonio Rusconi, ex-magistrato alle Acque.

\section{Documents}

UNESCO, 2011. Venice and its Lagoon: Management Plan 2012-2018. http://www.veniceandlagoon.net/web/wp-content/uploads/2014/12/MP volume low eng.pdf

Contratto di Costa : http://contrattodifocedeltadelpo.com/2016/03/06/erosione-e-problematichedella-costa-veneta-il-ministro-galletti-a-bibione-per-lavvio-del-contratto-di-costa-veneta/

Geodatabase gestionale delle coste venete (Coastal management geodatabase) http://sistemavenezia.regione.veneto.it/sites/default/files/documents/08_Shape/RelazioneGCVrev-ott2015_0.pdf

Tavolo Nazionale Erosione Costiere (National Coastal Erosion Group), http://www.isprambiente.gov.it/it/news/istituito-il-tavolo-nazionale-sull2019erosione-costiera

Dune e strumenti di pianificazione: il piano dell'arenile del Lido di Venezia. (Dunes and planning tools: the Lido di Venezia beach plan). (https://www.researchgate.net/publication/242162339 Dune e strumenti di pianificazione il _piano_dell'arenile_del_Lido_di_Venezia)

Veneto Regional Government. Dipartimento del Suolo e Foreste, Sezione Difesa del Suolo Gestione integrate della fascia costiera: studio e monitoraggio per la definizione degli interventi di difesa dei litorali dall'erosione nella regione Veneto, linee guida (Integrated management of the coastal zone: Study and monitoring for the definition of the interventions to protect the coasts from erosion in the Veneto region, guidelines).

Autorità Portuale (Port Authority):_11-14 ottobre 2016: Green Port Conference https://www.port.venice.it/it/green-port-conference-2016.html 